Portland State University

PDXScholar

2-5-1993

\title{
Language and Memory Development in the Three and Four Year Old
}

Caroline Prater Moffatt

Portland State University

Follow this and additional works at: https://pdxscholar.library.pdx.edu/open_access_etds

Part of the Speech and Rhetorical Studies Commons

Let us know how access to this document benefits you.

\section{Recommended Citation}

Moffatt, Caroline Prater, "Language and Memory Development in the Three and Four Year Old" (1993). Dissertations and Theses. Paper 4628.

https://doi.org/10.15760/etd.6512

This Thesis is brought to you for free and open access. It has been accepted for inclusion in Dissertations and Theses by an authorized administrator of PDXScholar. Please contact us if we can make this document more accessible: pdxscholar@pdx.edu. 
AN ABSTRACT OF THE THESIS OF Caroline Prater Moffatt for the Master of Science in Speech Communication: Speech and Hearing Sciences presented February 5, 1993.

Title: Language and memory Development in the Three and Four Year old.

APPROVED BY THE MEMBERS OF THE THESIS COMMITTEE:

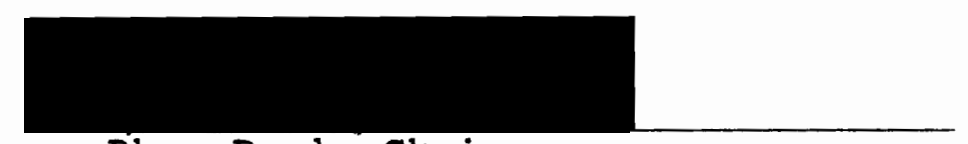

$$
\text { Rhea Paul, Chair }
$$
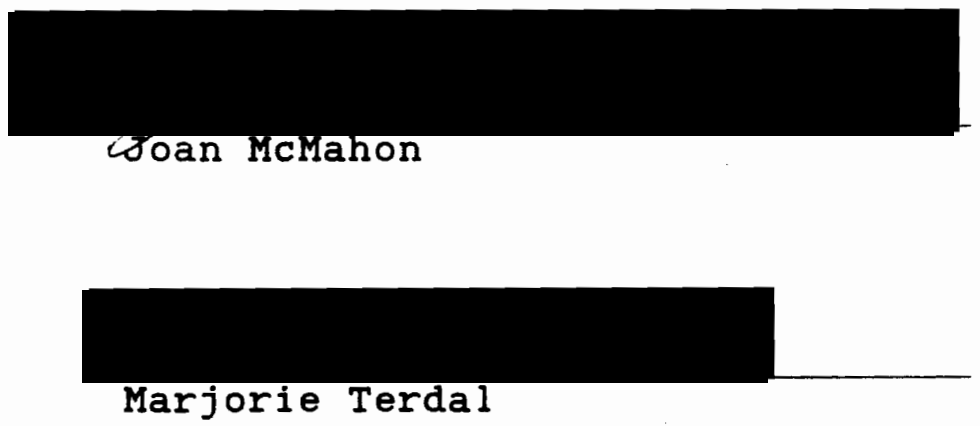

Although there is agreement in the 'literature that memory is required for language, there is disagreement as to whether certain memory abilities are prerequisite for language. There has been a significant amount of research in the field of memory development as it relates to language; however, little research has been done in the area of memory and language development in the preschool 
aged child.

This study examined two aspects of auditory memory and language development in the preschool child: (a) the auditory memory abilities of delayed language children versus normal language children, and (b) determining if there is a relationship between auditory memory and language development.

The subjects used in this study included 14 "normal talkers" and 14 children with "slow expressive language development" (SELD), as determined by the Language Development Survey (Rescorla, 1989) given when the subjects were between 24-34 months of age. When the subjects were 3 years-old they were given the verbal and digit imitation section of the Preschool Language scale (PLS) as a measure of auditory short-term memory. The results were compared with the Test of Auditory Comprehension of Language-Revised $(T A C L-R)$, the Developmental sentence scoring (DSS) and the Northwestern syntax Screening Test (NSST-E) all given at age three. A further comparison was made with the PLs and the Test of Language Development-Primary (TOLD-P) and the DSS, given at age 4. The spearman rank correlational statistic was used to determine if a significant relationship existed between memory and language development as seen on the PLS (age 3) and the other language measures given at ages 3 and 4 .

This study showed that SELD children performed more 
poorly on verbal and digit memory tasks than their normally speaking peers. Correlational analysis revealed that the PLS-Digit and the PLS-Sentence memory recall tasks were significantly correlated with the DSS given at the same point in time for the normal group, and between the PLS-Sentence and the NSST-E given at the same time for the SEID group. This suggests that a relationship exists between memory and expressive language at the same point in development. Because the relationship exists at the same time, and not across-ages, these findings seem to support the theory that language and memory are related in development, but memory skills at one time do not predict language skills at another.

As language and memory seem to be related at the same point in time, testing auditory short-term memory skills in children with language delays will not add new information above what is learned in language testing itself. Further research in this area might investigate whether, as some literature suggests (Kail, 1990), teaching memory strategies to young children with language delays may improve language learning. 


\title{
LANGUAGE AND MEMORY DEVELOPMENT
}

IN THE THREE AND FOUR YEAR OLD

\author{
by
}

CAROLINE PRATER MOFFATT

A thesis submitted in partial fulfillment of the requirements for the degree of

\author{
MASTER OF SCIENCE \\ in \\ SPEECH COMMUNICATION : \\ SPEECH AND HEARING SCIENCES
}

Portland State University

1993 


\section{TO THE OFFICE OF GRADUATE STUDIES:}

The members of the Committee approve the thesis of Caroline Prater Moffatt presented February 5, 1993.

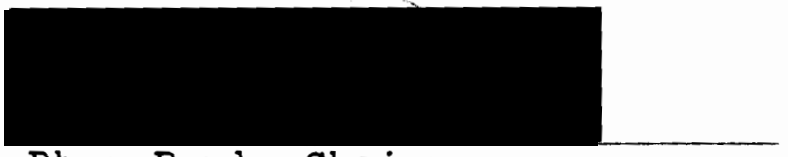

Rhea Paul, Chairperson

Coan McMahon

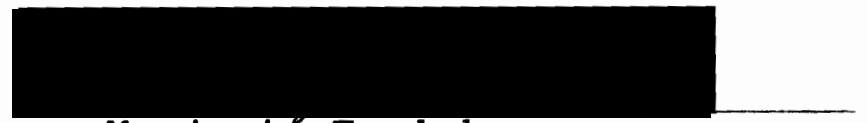

Marjorie Terdal

APPROVED :

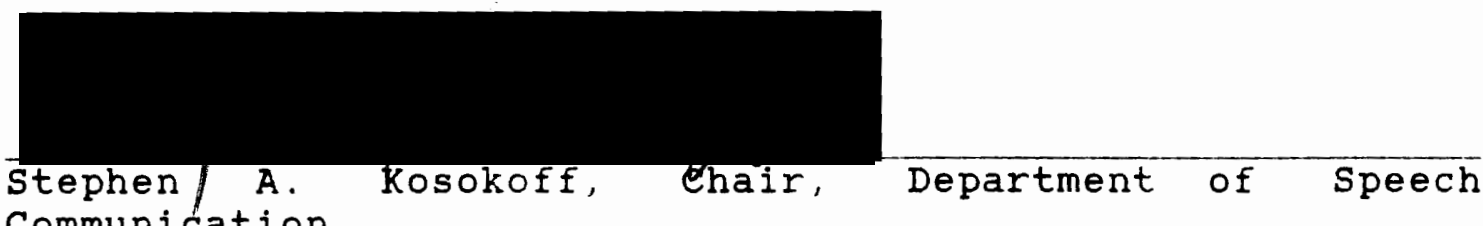
Communication

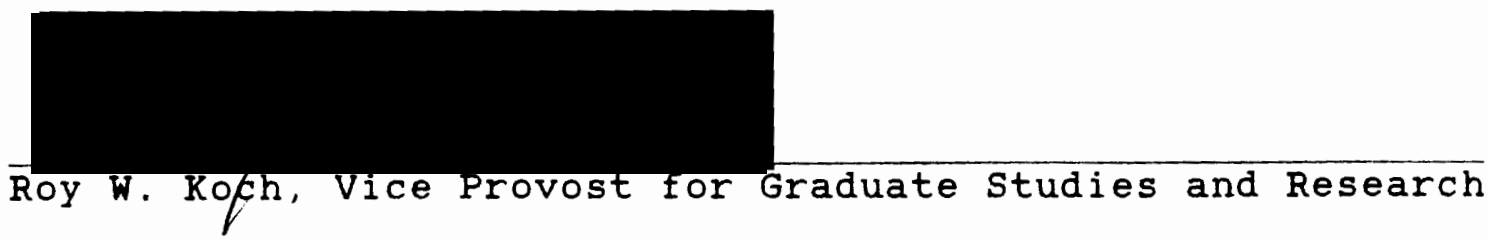




\section{ACKNOWLEDGEMENTS}

This is dedicated to my family, Al, John and Michelle, for putting up with me throughout this project and my graduate career.

I would like to thank the members of my thesis committee, Joan McMahon and Dr. Marjorie Terdal, for their time and advice. I would especially like to thank my thesis chairperson, Dr. Rhea Paul, for all her patience and rewrites over the last year -- I could not have done it without her! 
TABLE OF CONTENTS

PAGE

ACKNOWLEDGEMENTS . . . . . . . . . . . . . . . . . i ii

LIST OF TABLES . . . . . . . . . . . . . . . . . . . . vi v v

\section{CHAPTER}

I INTRODUCTION AND STATEMENT OF PURPOSE . . . 1

Introduction . . . . . . . . . . . . . 1

Rationale . . . . . . . . . . 3

Statement of Purpose........ . . 4

Definition of Terms . . . . . . . 5

I I REVIEW OF THE LITERATURE . . . . . . . . . . . . . 7

Auditory Memory Skilis: Types and

Terminology . . . . . . . . . . . 7

Auditory Short-term Memory Long-term Memory

Language and Memory . . . . . . . 11

Summary . . . . . . . . . . . . . 13

II METHODS AND PROCEDURES . . . . . . . . . 15

Subjects . . . . . . . . . . . . 15

Recruiting Procedures

subject selection for Current study

Procedures. . . . . . . . . . . 18

Follow-up

Instruments . . . . . . . . . . 20

Preschool Language Scale 
Nortwestern Syntax screening

$$
\text { Test }
$$

Test of Auditory Comprehension of Language

Developmental sentence scoring

Test of Language Development Reliability

Analysis and Design . . . . . . . 23

IV RESULTS AND DISCUSSION . . . . . . . . . . 25

Results... . . . . . . . . . 25

Correlation with the PLS-Digit

Correlation with the PLS-Sentence

Discussion. . . . . . . . . . . 29

Results of the PLS-Digit

Results of the PLS-Sentence

V SUMMARY AND IMPLICATIONS . . . . . . . . . . 32

Summary . . . . . . . . . . . . . 32

Implications . . . . . . . . . . 33

Clinical Implications

Research Implications

SELECTED BIBLIOGRAPHY . . . . . . . . . . . . . 35

APPENDICES

A PARENT CONSENT FORM . . . . . . . . . . . . 40

B PRESCHOOL LANGUAGE SCALE . . . . . . . . 42

C NORTHWESTERN SYNTAX SCREENING TEST . . . 46

D TEST OF AUDITORY COMPRESHENSION OF LANGUAGE-

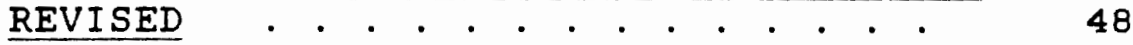

E DEVELOPMENTAL SENTENCE SCORING . . . . . 53

F TEST OF LANGUAGE DEVELOPMENT- PRIMARY .

G SUBJECT DATA . . . . . . . . . . . . . 60 


\section{LIST OF TABLES}

TABLE

PAGE

I Capacity of STM, Plus or Minus 1. . . .

I Demographic Information for the Normal and SELD Groups . . . . . . . . . . . .

II Results of the SELD and Normal Groups

Matched on the Draw-A-Person for

Nonverbal Cognitive Maturity . . . . .

IV Mental Age Validity for the Draw-a-

Person . . . . . . . . . . . . 20

$\mathrm{V}$ Measures Given to Subjects at Ages 3 and

4. . . . . . . . . . . . . . . . 21

VI Mean, $t$-Test, standard Deviation and

Range of Each Group for Each of the

Dependent Measures . . . . . . . .

VII Results of the Spearman Rank Correlation

Coefficient for the Normal and SELD

Groups . . . . . . . . . . . . . 


\section{CHAPTER I}

\section{INTRODUCTION AND STATEMENT OF PURPOSE}

\section{INTRODUCTION}

Interest in the study of children's memory development can be traced back to the late $1800^{\prime} \mathrm{s}$, when the study of psychology was a new discipline. Jacobs, in 1887, and Kirkpatrick in 1894, found age differences in digit span recall. Binet and Henri, also in 1894, began studying recall of related and unrelated words. At the turn of the century, memory research was limited to the study of the relationship between memory and intelligence. It was not until the 1960s that researchers focused on the diagnostic aspects of the memory span test, and attempted to understand factors that might be responsible for age related improvements (Chi, 1976;, Ornstein, 1978; Flaveli, $1985)$.

The relation between children's memory skills and their language ability has also been of interest. Some authors (Clarke-stewart, Perlmutter \& Friedman, 1988; Carter, 1989; Chalfant \& Scheffelin, 1969; Atkinson \& Shiffin, 1971) suggest that children have language problems that may result from deficient memory skills as they depend on auditory memory for the development of communication. 
The present study examines performance on memory tasks in children with normal and delayed language development. Its intent is to investigate the role played by memory in language development and delay.

Whereas memory span tests of digits examine shortterm memory (STM) alone, the ability to repeat sentences relies on both STM and long-term memory (LTM) (Zimmerman, Steiner \& Pond, 1979). Both STM and LTM are an intergral part of language processing as they bring together linguistic, cognitive and perceptual abilities (Carter, 1989; Wiig \& Semel, 1984; Wiig \& Semel, 1976). Information is stored in STM for up a few seconds to 1 minute before it is retained in LTM or forgotten (Ault, 1983; Carter, 1989; Adams, 1976; Chalfant \& Scheffelin, 1969). In LTM the perceived stimulus is recognized and identified. Without LTM, all incoming data would appear new and unique no matter how repetitious (Flowers, 1983).

Both LTM and STM are involved in language development; more specifically, auditory short-term and long-term memory are important in the acquisition of language (Wiig \& Semel, 1984; Chalfant \& Scheffelin, 1969). Auditory short-term memory (ASTM) involves the ability to discriminate sounds and combine them into words and sentences. This discrimination is thought by some to be a major stepping stone for the development of syntax (Carter, 1989; Mountain, 1980; Witkin, 1971). 
ASTM is comprised of two subskills: span (the maximum number of words, digits or syllables retained after one presentation), and sequence, or the recall of a series of sounds in the correct order after one presentation (Carter, 1989; Cofer, 1976; Aten, 1974). Span and sequence development are held by some authors (Carter, 1989; Atkinson and Shiffen, 1971; Cofer, 1976; Adams, 1976) to be especially important to language development as the child relies on ASTM to remember incoming stimuli, to order the stimuli into words and sentences, and to respond correctly. An alternative view to the theory that memory skills are a prerequisite for language ability is presented by Lahey (1988), Bloom and Lahey (1978), Olson (1973), and Speidel and Herreshoff (1989). According to these theorists, language development itself affects STM, as the child uses language to increase skill and strategy for storing and retrieving auditory information.

\section{RATIONALE}

Language and communication development are thought by some authors to be dependent upon a working auditory memory system, (Carter, 1989; Rosenblum, 1979). This study will determine if auditory memory testing at age three can predict later language ability in children with normal and delayed language development. The study will test the hypothesis that auditory memory ability is a prerequisite 
for language development, and that memory deficits in children with language delays are correlated with their progress in language skills.

\section{STATEMENT OF PURPOSE}

The purpose of this study is to investigate the relationship between the auditory memory skills of 3 yearolds with normal and delayed language development, and the language ability of the same children tested at ages 3 and 4. The research hypotheses of the study are that 1) auditory memory skills in children with delayed language will be poorer than those of children with normal language development, and 2) that auditory memory skilis have a positive correlation with language development. The specific question to be investigated is: is there a correlation between the results of the verbal (PLSSentence) and Digit (PLS-Digit) imitation section of the Preschool Language scale (PLS), with the Developmental Sentence scoring (DSS-age 3), the Northwestern syntax screening Test (NSST-E), and the Test of Auditory Comprehension of Language $(T A C L-R)$ at age 3 , and with the DSS (DSS-age 4), and the speaking (TOLD-S) and Listening (TOLD-L) section of the Test of Language Development (TOLDP) given at age 4?

The Research Hypothesis. The research hypotheses for this study are that auditory memory skills are depressed in 
children with delayed language and that auditory memory skills have a positive correlation with language development.

The Null Hypothesis. The null hypothesis is that memory is not necessarily a prerequisite to language, but the two abilities are related in a more general way without one necessarily being a prerequisite to the other.

\section{DEFINITION OF TERMS}

Auditory long-term memory: The memory of auditory experiences that modifies all perception and makes possible the recognition and identification of the many sounds occurring in the environment (Flowers, 1983).

Auditory short-term memory: Holds and retrieves information for a short period of time ( 1 second to 1 minutes) (Wallace \& McLoughlin, 1988; Clarke-stewart et a.., 1988).

Auditory short-term sequential memory: Retrieving information in the same order received (Wallace \& McLoughlin, 1988).

Auditory short-term memory span: Retention and recall, not necessarily in sequential order (Burford, 1976). The maximum number of digits, words or syllables retained after one presentation (Cofer, 1976).

Normal talkers: Children whose parents reported the use of more than 50 different words and used productive two 
word combinations at age 24-34 months on the Language Development Survey (Rescorla, 1989).

Recall: Process of remembering, reconstructing and activating language stored in memory (Wiig \& Semel, 1984). Recognition: Process of recognizing a previous stimulus and matching that stimulus to stored memory (Wiig \& Seme1, 1984).

Retrieval: Process of bringing back language from storage in memory for production and use in spoken language (Wiig \& Semel, 1984).

Slow expressive language development (SELD) group: Children who, at 24-34 months of age, used fewer than 50 different words or no two word combinations, as reported by parents on the Language Development Survey. 
CHAPTER I I

REVIEW OF THE LITERATURE

The literature available covers many types of memory, including long-term and short-term memory. Within both LTM and STM different types of memory can be found, including: auditory or echoic memory which is imitation of a sound; visual or iconic memory which is recall of visual images; and enactive memory, or recall of motoric activity. As auditory memory would appear to be a natural precursor to language development, this review will focus on findings within auditory memory with special attention to auditory short-term memory tasks.

\section{AUDITORY MEMORY SKILLS: TYPES AND TERMINOLOGY}

\section{Auditory Short-term Memory}

One way STM receives stimuli is through echoic, or auditory modalities (Davis, 1984; Gerber, 1981). Auditory short-term memory is defined by Adams (1976) as input items being held in unprocessed sensory form by the listener. Auditory short-term memory is the ability to temporarily retain the characteristics of a sound or series of sounds (Davis, 1984; Heasley, 1974; Flowers, 1983).

Auditory short-term memory consists of two subskills: 
span and sequence (Wallace \& McLoughlin, 1988; Heasley, 1974). Auditory memory span and sequence are necessary to discriminate and order incoming stimuli to respond in an appropriate manner (Carter, 1989; Davis, 1984; Atkinson \& Shiffin, 1971).

Span. Auditory short-term memory span is the temporary retention of a sequence of events or words associated together for immediate reproduction (Case, 1985; Flowers, 1983; Masland and Case, 1968). The number of related or unrelated items that can be recalled immediately after presentation makes up the auditory memory span. Auditory memory span holds digits, letters, isolated words and words in sentences for recall (Cantwell \& Baker, 1987; Cofer, 1976). By increasing the number of stimuli presented, the amount the child or adult is able to retain and retrieve is tested (Kail, 1990; Flavel1, 1985; Hulme, Thomas, Muir \& Lawrence, 1984; Chalfant \& Scheffelin, 1969). LaBenz and Fay (1980) tested the ability to repeat a series of digits and words after one presentation, for three to eight year olds on digit span, syllables and spondaic words memory tests. Ninty-three percent could repeat a 2 digit series, $74 \%$ could repeat 3 digit series, $95 \%$ were correct on 2 syllable word series and $78 \%$ on 3 syllable word series. According to Zimmerman, steiner and Pond (1979), at 2-6 to 3 years, the ability to repeat a 3 digit series is representative of an increasing ability in listening skills 
and in STM. Table I shows Chi's (1976) comparison of average digit, word and letter recall, plus or minus 1 , at age 5 and at adulthood.

\section{TABLE I}

CAPACITY OF STM, PIUS OR MINUS 1

AGE

DIGIT

LETTER

WORD

5

4.3

3.69

4.3

Adult

7.98

7.21

5.86

Source: Chi, 1976

Commonly, repetition of digits is used to measure auditory short-term memory span (Boyd \& Hooper, 1987; Case, 1985; Wepman \& Morency, 1973; Carrow, 1974). Digit recall is common in intelligence testing. Although some researchers (Schofield \& Asman, 1986; Chase, Lyon \& Ericsson, 1984; Nicolson, 1984; Wepman \& Morency, 1973; Olson, 1973) have found that forward and backward digit span, chronological age and IQ are highly correlated (.50 .60), others (Torgesen, 1990) suggests that memory span tasks are not highly correlated with general intelligence. As a diagnostic tool, digit span gives estimates of a child's ability to learn; however, it does not necessarily indicate a high degree of comprehension, only the possibility of retention of comprehended auditory stimuli (Gardner, 1985). The use of digit span is perceptual because it requires repetition without meaning and therefore 
utilizes many of the processes that determine the functional storage capacity of short-term memory (Torgesen, 1990; Wepman \& Morency, 1973; Gardner, 1985). Immediate recall of auditory stimuli is thought by some researchers to be necessary for adequate intellectual functioning and the development of language skills (Wiig \& Semel, 1984; Wiig \& Seme1, 1976). However, Cantwell \& Baker (1987) agree that representation of digits, words and sentences can be indicative of auditory memory deficits, they feel that performance on repetition of nonsense words and strings of unrelated words is more specifically related to language dysfunction.

Sequence. As with auditory memory span, sequencing is thought to be critical in language development, comprehension and expression (Wallace \& McLoughlin, 1988; Heasley, 1974; Carrow, 1974). Auditory short-term sequential memory allows for the retention and reproduction of auditory information in sequential order (Wallace \& McLoughlin, 1988; Faas, 1980). Tasks used to measure this ability include repetition of nonmeaningful digits and unrelated words (Faas, 1980; Wallace \& McLoughlin, 1988). Readiness for syntax is thought to be dependent upon the number of verbal items a child can hold in sequential order for immediate recall and use (Carter, 1989; Wepman \& Morency, 1973).

\section{Long-term memory}

Whereas STM temporarily holds incoming auditory 
information, ITM gives meaning to the input. If a child can not relate a portion of the surface structure, or utterance, to his or her existing deep structure knowledge base for meaning, the sentence will be recalled in the same way as an unrelated series of words (Lahey, 1988; Carrow, 1974; Olson, 1973). Familiarity of the words and grammatical sequences used, and the retrieval of words from LTM permit the comprehension of linguistic information (Flowers, 1983). A child must be able to store, assimilate and retrieve information from LTM in order for language comprehension to be accomplished (Clarke-stewart et al, 1988; Carter, 1989; Lerner, 1971).

Sequence. Tasks used to measure long-term sequential memory include repetition of sentences, counting, and reciting the alphabet and the days of the week (Faas, 1980; Wallace \& McLoughlin, 1988).

\section{LANGUAGE AND MEMORY}

Repetition of sentences for immediate recall depends on STM for span and LTM for the application of deep structure or meaning (Speidel, 1989; Clarke-stewart et al, 1988; Olson, 1973), which in turn provides the basis for sequence. A child will omit from the surface structure those linguistic elements which cannot be related to deep structure for meaning (Lahey, 1988; Bloom \& Lahey, 1978; Olson, 1973; Wepman \& Morency, 1973). Without meaning from 
the deep structure, the sentence imitated would be limited by STM span. Without information from LTM, children would not be able to repeat sentences with more words than the number of unrelated digits their short-term memory span was able to retain (Lahey, 1988; Carrow, 1974). Therefore, sentences presented for immediate recall help to determine what the child already understands about the structure of the sentences (Lahey, 1988; Bloom \& Lahey, 1978). As a result, children will process sentences which exceed their auditory memory span only if the sentence structure is understood. If the structure is not understood, the child will treat the sentence as a word list (Lahey, 1988; Carrow, 1974). From immediate imitation of the sentence it is thought to be possible to determine what is understood of the content and structure of the sentence (Lahey, 1988; Cantwell1 \& Baker, 1987; Bloom \& Lahey, 1978; Carrow, 1974). This argument also suggests that language skill itself can affect performance on memory for sentence tasks. If a child has not mastered the language found in the sentence, the sentence will be repeated at the level of language ability the child does have.

Sentence repetition involves the recall of the temporal order of elements within sentences (Carter, 1989; Masland \& Case, 1968). The sequence of the words within a sentence is determined by the syntactic rules of the language; therefore, it may be inferred that the inability to remember 
sequences might interfere with the ability to internalize the syntactic order and rules of the language (Carter, 1989; Masland \& Case, 1968).

Conversely, the inability to repeat sentences may reflect a lack of syntactic knowledge which would result in the appearance of depressed performance on sentence memory tasks. This model of language processing holds that memory is not necessarily a prerequisite to language, but rather that auditory sequential recall tasks are an indicator of linguisitc familiarity (Lahey, 1988; Bloom \& Lahey, 1978). Performance deficits in young children on short-term memory tasks are seen in this view as the result of failure to organize, plan and integrate new information effectively, or the inability to use deep structure knowledge to aid recall (Olson, 1973; Huttenlocher \& Burke, 1976). Further, poor auditory memory span in language disordered children may be due to the language deficit itself and not a processing ability (Lahey, 1988; Bloom \& Lahey, 1978).

\section{SUMMARY}

This study will address the question of whether performance on ASTM tasks can predict later language development. ASTM skill is thought by many authors reviewed here to be a prerequisite for later language ability (Carter, 1989; Clarke-stewart et al, 1988; Chalfant \& Scheffelin, 1969; Witkin, 1971; Faas, 1980; Adams, 1976; 
Gerber, 1981). If this theory is correct then this study would expect to find that children with delayed language are poorer in ASTM than normal peers, and that there will be a correlation between ASTM ability at age 3 and language at age 4. It would agree with the model which holds that auditory memory allows for recognition and discrimination of units within sentences. Further, it would suggest that auditory memory sequencing is most critical in language development as it allows for the serial reproduction of information from memory (Faas, 1980).

If language itself contributes to the performance on ASTM tasks, as Lahey (1988) and Bloom and Lahey (1978) claim, then a correlation might be found between ASTM and language at age 3 , but the correlation of ASTM and language at age 4 would be less strong than the correlation of language ability at 3 and 4 . ASTM and language at age 3 would be related in that language skill would influence ASTM, as this model predicts, but language itself would be a better predictor of later language ability than would ASTM. This finding would support the notion that language ability has a greater effect on memory performance than vice versa. 


\section{CHAPTER III}

\section{METHODS AND PROCEDURES}

\section{SUBJECTS}

The subjects used for this study are participants in the Portland Language Development Project (PLDP), a longitudinal study of early language delay.

This study was concerned with a comparison between two groups of children: a group with slow expressive language development (SELD, $n=14$ ) and a group with normal language development (NI, $n=14$ ). The Language Development Survey (LDS) (Rescorla, 1989) was used to determine group assignment. The LDS is a parent questionnaire consisting of a checklist of the 300 most common words in children's early vocabularies and a section questioning parents on children's use of word combinations. Rescorla (1989) reports high reliability, validity, sensitivity, and specificity for use of the LDS to identify language delay in this age range. SELD is defined in this study as the use of fewer than 50 different words or no use of two word combinations at age 24-34 months as reported by parents on the LDS. NL is defined as the use of more than 50 different words on the LDS, and the use of productive two-word combinations at this age level. 


\section{Recruiting Procedures}

Two procedures were followed in recruiting the subjects. In the first procedure, receptionists and nurses handed out questionnaires to parents bringing in their children for 15 and 24 month well-baby checks. Based on the information provided by the parents, the children were classified as having SELD or normal expressive language as determined by the criteria above.

The second procedure was to contact parents who responded to a local newspaper ad or radio news station requesting speech-delayed toddlers to participate in a longitudinal study. The same questions were asked of these parents and a classification of SELD or normal was made for each child. All parents of children identified as SELD were invited to join the longitudinal study. A control group of NL families, selected to match the SELDs on the basis of age, sex ratio and SES, was also invited to participate.

\section{Subject selection for Current study}

The subjects who participated in the current study were selected from the pool of subjects in the PLDP. For both the SELD and the normal groups, $93 \%$ were Caucasian (see Table II). The mean socio-economic level, based on Myers and Bean's (1968) modification of the Hollingshead four factor scale of social status, was 2.6 for the normal group and 3.0 for the SELD group. This places the two groups in 
TABLE II

DEMOGRAPHIC INFORMATION FOR THE

NORMAL AND SELD GROUPS

Norma 1

SELD

\# Age Sex Race sEs

\# $\begin{gathered}\text { Age Sex } \\ \text { (months) }\end{gathered}$

$14 \quad 37$

M

W 1

636

M W 2

$51 \quad 38$

F

W

4

$7 \quad 36$

M W 2

$55 \quad 38$

F

W

3

$\begin{array}{lll}58 & 42 \quad M\end{array}$

W 1

$63 \quad 36$

M

W

3

$\begin{array}{ll}72 & 37\end{array}$

M

W

4

9536

M

W

3

$128 \quad 38 \quad M$

W

2

$130 \quad 38$

M

W

3

$29 \quad 38$

$\mathbf{F}$

พ 5

$13139 \quad M$

W

2

5340

M

$54 \quad 43$

M

W 4

13236

$13336 \quad M$

$\operatorname{Mix} 1$

$57 \quad 42$

$\begin{array}{lll}85 & 37 \quad M\end{array}$

$87 \quad 37$

F

$9243 \quad M$

W 3

14438

W

4

10240 M W 2

$\begin{array}{lllll}150 & 37 & \text { F } & \text { W } & 1\end{array}$

Total: $\quad \mathrm{N}=14,73 \% \mathrm{male}$

$X$ age: 37.6 months

$X$ race: $93 \%$ white

$X$ SES: 2.6

$\begin{array}{llll}105 & 37 & M & \text { W }\end{array}$

$11436 \quad M \quad$ Mix 2

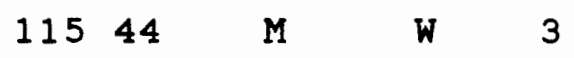

$\begin{array}{lllll}119 & 36 & M & \text { W } & 2\end{array}$

$N=14,73 \%$ male

$X$ age: 39.0 months

$X$ race: $93 \%$ white

$X$ SES: 3

the middle to lower-middle class. All children passed a hearing screening at $25 \mathrm{dBHL}$ and scored at least 85 on the Bayley scale of Infant Development (Bayley, 1969). Children in both groups were included only if they had no 
known physical handicaps, mental retardation, neurological disorders or autism. Children were seen for longitudinal follow-up at ages three and four.

For the present study, NL and SELD groups were selected so as to be matched on the basis of sex ratio and scores on the Harris-Goodenough (Goodenough \& Harris, 1963) Draw-a-person (DAP) test, used as an index of nonverbal cognitive maturity (see Table III). The Draw-A-Person mental age validity as compared to the standford-Binet and the WPPSI is included in Table IV (Harris, 1963). The SELD group involved in the present study had 11 males and 3 females ( $73 \%$ male) with a mean age at the three year follow up evaluation of 39 months and a standard deviation of 2.57 . The normal group had 14 subjects with 11 males and 3 females $(73 \%$ male). The average age at the three year follow up evaluation for the NLs was 37.6 months (s.d.9.0).

\section{PROCEDURES}

The first indepth evaluation of the children for this longitudinal study was made at intake into the PLDP in 1987 , at age 2. During the intake assessment, the parents signed permission forms to participate in the study (Appendix $A$ ). At this time they were given the LDS. All subjects retained their original diagnostic group classification by this measure. Indepth assessment of language and related skills were carried out at this time (Paul, 1991). 
TABLE III

RESULTS OF THE SELD AND NORMAL GROUPS MATCHED ON DRAW-A-PERSON FOR

NONVERBAL COGNITIVE MATURITY

NORMAL

\begin{tabular}{|c|c|c|c|c|c|}
\hline subject & DAP & Sex & subject & DAP & Sex \\
\hline 14 & 105 & M & 6 & -- & $\mathbf{M}$ \\
\hline 51 & 134 & $\mathbf{F}$ & 7 & 108 & $M$ \\
\hline 55 & 103 & $\mathbf{F}$ & 29 & 103 & $\mathbf{F}$ \\
\hline 58 & 93 & $\mathbf{M}$ & 53 & 93 & $\mathbf{M}$ \\
\hline 63 & 108 & M & 54 & 91 & $\mathbf{M}$ \\
\hline 72 & -- & $\mathbf{M}$ & 57 & 100 & $\mathbf{F}$ \\
\hline 95 & 108 & M & 85 & -- & $\mathbf{F}$ \\
\hline 128 & 103 & $\mathbf{M}$ & 87 & 133 & $F$ \\
\hline 130 & 111 & $\mathbf{M}$ & 92 & 91 & $\mathbf{M}$ \\
\hline 131 & 100 & $\mathbf{M}$ & 102 & 98 & M \\
\hline 132 & 152 & M & 105 & 166 & $\mathbf{M}$ \\
\hline 133 & 105 & $\mathbf{M}$ & 114 & 108 & $\mathbf{M}$ \\
\hline 144 & 103 & M & 115 & -- & $\mathbf{M}$ \\
\hline 150 & 108 & $\mathbf{F}$ & 119 & 108 & $\mathbf{M}$ \\
\hline
\end{tabular}

Tota 1:

$\begin{array}{llll}\mathrm{N}: & 14,73 \% \text { male } & \mathrm{N}: & 14,73 \% \text { male } \\ \mathrm{X} \text { IQ: } & 110 & \mathrm{X} \text { IQ: } & 109 \\ \text { SD }: & 15.7 & \text { SD } & 22.0 \\ \text { Range: } & 93-152 & \text { Range: } 91-166\end{array}$

Fo1 low-up

subjects were seen for yearly reevaluations of language and related skills at age 3 and again at age 4 . At age 3 , 
the normal and SELD group were given the verbal/Digit Imitation section of the Preschool Language scale (PLS) (Zimmerman, steiner and Pond, 1979) (Appendix B), the expressive portion of the Northwestern syntax Screening Test (NSST-E) (Lee, 1971) (Appendix C), and the Test of Auditory Comprehension of Language- Revised (TACL-R) (Carrow, 1985) (Appendix D). The Developmental sentence scoring (DSS) (Lee, 1974) (Appendix E) was obtained by analyzing a 10 minute language sample collected during free play between the mother and child at ages 3 and 4. At age 4 the children were also given the Test of Language DevelopmentPrimary (TOLD-P) (Newcomer, Hammill, 1988) (Appendix F). The DSS was obtained again at age 4, using procedures similar to those used at age 3.

\section{TABLE IV}

MENTAL AGE VALIDITY

FOR THE DRAW-A-PERSON

\begin{abstract}
MEASURE
Standford-

Binet
\end{abstract}

WPPS I

$$
\text { NUMBER }
$$

IN STUDY

$$
100
$$$$
116
$$

AGE

$3-15$

4

5

5
VALIDITY

(Pearson $r$ )

$$
\begin{aligned}
& r=.80 \\
& r=.74 \\
& r=.78
\end{aligned}
$$

$r=.72-.80$

\section{INSTRUMENTS}

At age 3 the subjects were given the PLS, the NSST, the TACL-R and the DSS. At age 4 the same subjects were given the TOLD-P and the DSS (Table V). 
TABLE V

MEASURES GIVEN TO SUBJECTS AT AGES 3 AND 4

$\begin{array}{cccccc}\text { AGE } & \text { PLS } & \text { NSST-E } & \text { TACL-R } & \text { DSS } & \text { TOLD-P } \\ 3 & \mathrm{X} & \mathrm{X} & \mathrm{X} & \mathrm{X} & \\ 4 & & & & \mathrm{X} & \mathrm{X}\end{array}$

Preschool Language scale

Both groups of children were given the Verbal/Digit Imitation section of the Preschool Language scale (PLS) at the follow-up evaluation when subjects were 3 years old. The PLS is designed to test verbal and auditory ability in children 1-6 to 7 years. The Verbal/Digit Imitation section tests repetiton of digits and sentences at 2 to 2-6 years and at the 2-6 to 3 year levels. Although not standardized, the items in the PLS were taken from existing standardized intelligence and developmental scales (Young, 1984). For ages 2 to 2-6 the PLS Digit span Section (PLS-Digit) tests recall of 2 digits given auditorily. At 2-6 to 3-0 the repetition of three digits is tested to measure the child's increasing STM span and listening ability. At both age levels, verbal repetition of short sentences is tested in the PLS-Sentence Imitation Section (PLS-Sentence). Whereas digit span tests listening ability and short-term memory development, sentence recall tests the preceding as well as language knowledge. 
Northwestern Syntax Screening Test

The Northwestern Screening Syntax Test- Expressive (NSST-E), is a screening instrument designed to estimate deviant syntactic development between 3 and 8 years. It was given at the 3-year-old evaluation of the PLDP. The NSST-E tests receptive and expressive ability; however, the 3-yearolds in this study were only given the expressive portion. The expressive portion requires delayed sentence repetition, which combines expressive and receptive skills. The results can be compared against norms developed for each age group.

Test of Auditory Comprehension of Language structure of Children, (TACL-R)

This test is a standardized test of auditory comprehension involving vocabulary, grammar and syntax. This test was administered at the 3-year evaluation.

\section{Developmental sentence scoring, (DSS)}

The DSS quantifies grammatical structures of expressive language. The DSS is frequently used in evaluating synatatic and morphological development in preschool children. Normative data are available for each age group from three through 8 years. This measure was collected from subjects at both three and four years of age.

Test of Language Development- Primary, (TOLD-P)

The TOLD-P is a standardized measurement device used to determine children's strengths and weaknesses in language 
skills. Composite scores are given for spoken language, listening, speaking, semantics, syntax and phonology. This test was given at the four-year evaluation.

\section{Reliability}

Reliability was obtained by having a second scorer record the responses of $10 \%$ of the subjects seen at the three year evaluation. Point-to-point inter-scorer reliability for the PLS-Digit reliability was 100\%, and on the PLS-Sentence reliability was at $83 \%$.

Reliability for the DSS scores was completed by having a second scorer independently rescore $10 \%$ of the transcripts from each of the 3 and 4 year evaluations. Point-to-point reliability for DSS points awards was $89.5 \%$ for the three year evaluation and $91.8 \%$ for the 4 year evaluation.

\section{ANALYSIS AND DESIGN}

To investigate the relationship between memory and language, a correlational design was utilized. This tests for an association between memory and language development, as seen in the standardized testing.

The data from the Verbal/Digit Imitation section of the Preschool Language scale was coded as to the total number of correct responses of sentence imitation (PLs-sentence score) and digit span (PLS-Digit score).

statistically, the data from the PIS are not normally distributed so a non-parametric, correlational statistic, 
the spearman rank-difference correlation, which scores and ranks each variable, was used for data analysis.

The smaller the difference between the summed ranks in each group, the higher the correlation between memory and language development. This would support the hypothesis that memory skills have a positive correlation with language development.

If the difference between summed ranks is large, the hypothesis would be rejected, and the study would fail to suggest a correlation between memory and language. This would support the theory proposed by Lahey (1988), Bloom and Lahey (1978) and olson (1973) which says that STM skills are not a prerequisite for language development. 
CHAPTER IV

RESULTS AND DISCUSSION

RESULTS

The specific objective of this study was to determine whether children with delayed language are poorer at memory skills than children with normal language and whether memory testing at age 3 can predict later language ability.

The research questions asked were: 1) Do SELDs score significantly lower on memory measures than the normal talkers, and 2) is there a correlation between the results of the Verbal/Digit Imitation section of the Preschool Language scale, with the Developmental sentence scoring, the Northwestern Syntax Screening Test, and the Test of Auditory Comprehension of Language structure of Children, at age 3 , and the Developmental Sentence Score, and the speaking and Listening sections of the Test of Language Development given at age 4 (See Appendix $G$ for results and data type).

The study showed that SELD children do perform more poorly on STM and LTM tasks than do their normally speaking peers. The relationship between the PLS-Digit and PLSSentence memory tasks and the various expressive and receptive tasks found few significant correlations, resulting in a failure to reject the null hypothesis of no 
relationship between early memory development and later language ability.

The means and standard deviations of the SELD group and the normal group were computed for each of the dependent variables. A t-test comparing the mean values of each variable for both groups was computed. The results are in Table VI. The test-statistic indicated that there was

\section{TABLE VI}

MEAN, $t$-TEST, STANDARD DEVIATION AND

RANGE OF EACH GROUP FOR EACH OF THE

DEPENDENT MEASURES

\begin{tabular}{|c|c|c|c|c|c|c|}
\hline Measure & Group & Mean & $t$-test & S.D. & & \\
\hline & & & & & $\mathrm{H}$ & L \\
\hline PLS-Digit & $\begin{array}{l}\text { Norma } 1 \\
\text { SELD }\end{array}$ & $\begin{array}{l}5.14 \\
3.0\end{array}$ & $3.51 *$ & $\begin{array}{l}1.1 \\
2.0\end{array}$ & $\begin{array}{l}6 \\
6\end{array}$ & $\begin{array}{l}2 \\
0\end{array}$ \\
\hline $\begin{array}{l}\text { PLS- } \\
\text { Sentence }\end{array}$ & $\begin{array}{l}\text { Normal } \\
\text { SELD }\end{array}$ & $\begin{array}{l}3.0 \\
.786\end{array}$ & $5.29^{\star}$ & $\begin{array}{l}2.0 \\
1.25\end{array}$ & $\begin{array}{l}4 \\
4\end{array}$ & $\begin{array}{l}1 \\
0\end{array}$ \\
\hline NSST-E & $\begin{array}{l}\text { Normal } \\
\text { SELD }\end{array}$ & $\begin{array}{l}9.36 \\
2.14\end{array}$ & $2.91 \star$ & $\begin{array}{l}8.0 \\
4.67\end{array}$ & $\begin{array}{l}21 \\
18\end{array}$ & $\begin{array}{l}0 \\
0\end{array}$ \\
\hline TACL-R & $\begin{array}{l}\text { Normal } \\
\text { SELD }\end{array}$ & $\begin{array}{l}36.6 \\
29.78\end{array}$ & 1.35 & $\begin{array}{l}8.96 \\
16.6\end{array}$ & $\begin{array}{l}63 \\
77\end{array}$ & $\begin{array}{l}22 \\
9\end{array}$ \\
\hline DSS-age 3 & $\begin{array}{l}\text { Normal } \\
\text { SELD }\end{array}$ & $\begin{array}{l}5.42 \\
3.75\end{array}$ & $2.79 \star$ & $\begin{array}{l}1.65 \\
1.51\end{array}$ & $\begin{array}{l}8.16 \\
6.12\end{array}$ & $\begin{array}{l}2.72 \\
.430\end{array}$ \\
\hline DSS-age 4 & $\begin{array}{l}\text { Norma } 1 \\
\text { SELD }\end{array}$ & $\begin{array}{l}6.55 \\
6.37\end{array}$ & .331 & $\begin{array}{l}1.50 \\
1.37\end{array}$ & $\begin{array}{l}8.62 \\
8.18\end{array}$ & $\begin{array}{l}4.07 \\
4.10\end{array}$ \\
\hline $\begin{array}{l}\text { TOLD- } \\
\text { Listening }\end{array}$ & $\begin{array}{l}\text { Normal } \\
\text { SELD }\end{array}$ & $\begin{array}{l}31.9 \\
24.57\end{array}$ & $2.49 *$ & $\begin{array}{l}6.46 \\
8.93\end{array}$ & $\begin{array}{l}39 \\
41\end{array}$ & $\begin{array}{l}29 \\
12\end{array}$ \\
\hline $\begin{array}{l}\text { TOLD- } \\
\text { speaking }\end{array}$ & $\begin{array}{l}\text { Normal } \\
\text { SELD }\end{array}$ & $\begin{array}{l}42.12 \\
37.14\end{array}$ & $2.12^{\star}$ & $\begin{array}{l}6.0 \\
6.46\end{array}$ & $\begin{array}{l}53 \\
49\end{array}$ & $\begin{array}{l}36 \\
26\end{array}$ \\
\hline
\end{tabular}

* Significant at $p<.001$.

d.f. $=26$ 
a significant difference $(p<.001)$ between the normal and SELD groups on all variables except for the TACL-R (given at age 3 ) and the DSS-Age 4. The differences between the means on memory tasks at age 3 were significant; however, the DSS-age 4 showed no significant difference between the two groups.

The data were further analyzed, using the spearman rank correlation coefficient, to determine if, in the normal or SELD group, a correlation existed between digit and sentence memory recall at 3 and language development at 3 and 4 . The results of the spearman rank correlation can be seen in Table VII.

\section{TABLE VII}

RESULTS OF THE SPEARMAN RANK CORRELATION COEFFICIENT FOR THE NORMAL AND SELD GROUPS

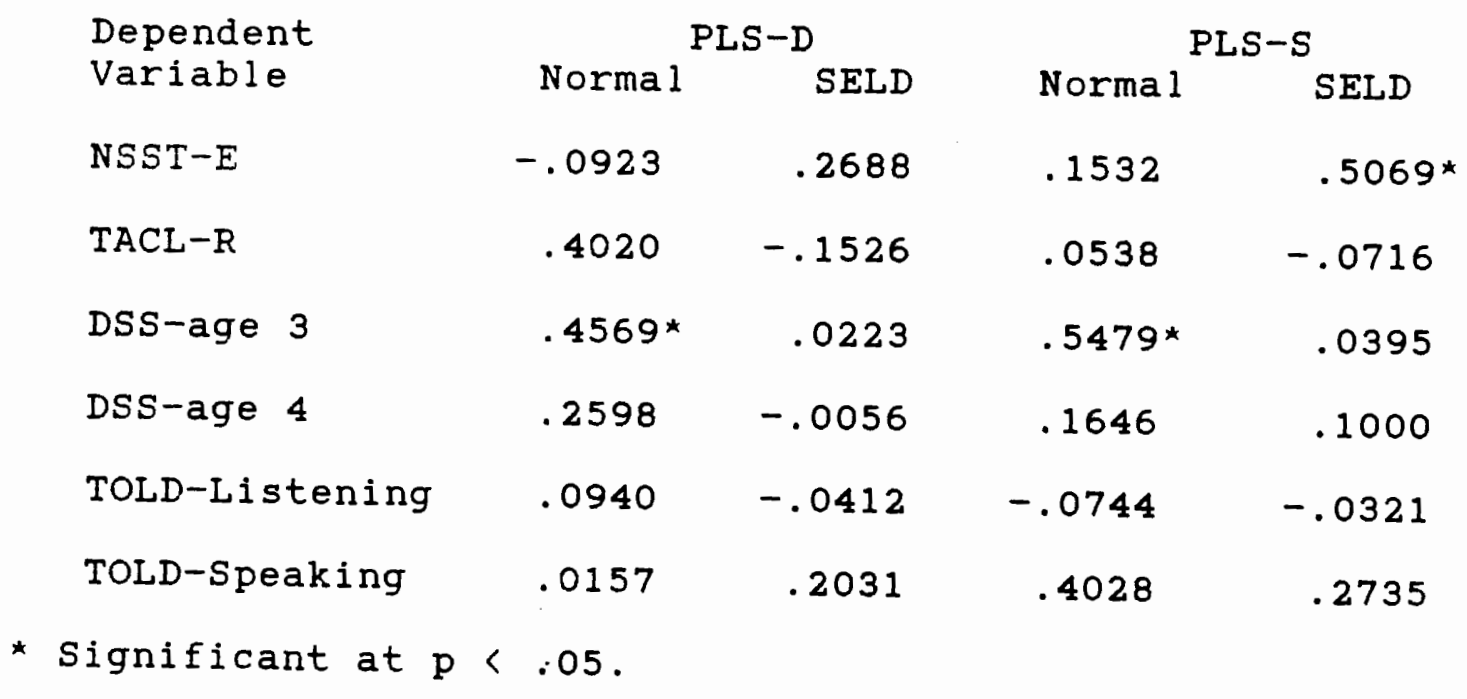

Correlation with the PLS-Digit

A correlation (at .05 level of significance) was found 
between the PLS-Digit and the DSS-age 3 for normal talkers. This indicates there may be a correlation between STM as measured by digit recall and the expressive language abilities of a normal child at the same age.

No significant correlations were found among the PLSDigit and the remaining dependent variables. This does not necessarily indicate that a relationship does not exist between these variables, only that there is insufficient evidence to conclude that a correlation exists.

\section{Correlation with the PLS-Sentence}

within the normal group, a positive correlation (at .025 level of significance) was found between the PLssentence and the DSS-age 3. Because the PLS-Digit also correlated with the DSs-age 3 , this could indicate a relationship between memory at 3 and expressive language at 3 within a normal population.

The NSST-E, an expressive sentence recall measure, was significantly correlated with the PLs-sentence among the SELD population. As the PLS-Sentence and the NSST-E both test sentence recall, a correlation between these measures is not surprising.

No significant correlations were found with the remaining dependent variables within either group. 
DISCUSSION

This study suggests that few significant correlations are seen between early memory and later language development. As can be seen in Table VI, the mean scores for the normal and SELD group were significantly different in all areas except the TACL-R and the DSS-age 4. The SELD group performed significantly more poorly on memory recall and on a variety of expressive language tasks at age three when compared to normal peers. However, by age 4 no significance in one measure of expressive language was seen, although there was a difference on another measure. This could be taken to suggest that SELDs are beginning to "catch up" in expressive language skills by age four. Still, digit span at age three does not appear to predict this "catching up." The fact that the SELD 3 year olds were poor in both memory and language performance at age three, but function within the normal range by age four could suggest that their delay is due to general maturational lag that affects a variety of cognitive functions, but can be overcome with time.

\section{Results of the PLS-Digit}

A significant correlation was found in the normal group for the digit memory recall and the DSS at age 3 . No other 
significant correlations were found with the PLS-Digit for either the normal or the SELD population.

The correlation found between the PLS-Digit and the DSS given at the same time indicates a relationship, within a normal population, between STM as measured by digit memory recall ability and expressive language development at a given point in time. The two abilities seem to develop in tandem. However, the PLS-Digit does not predict DSS scores one year later. This suggests support for Bloom and Lahey's hypothesis: language and short-term memory are related in development, but short-term memory does not predict and is not a prerequisite for language.

The correlation between digit span and expressive language skill does not hold true for the SELD group. This could suggest that SELD children are less efficient in bringing their STM skill to bear on the task of learning language.

Results of the PLS-Sentence

As with the PLS-Digit, there were few significant correlations with the PLS-sentence and the dependent variables. A significant correlation was found between the PLS-Sentence and the DSS score from the same year in the NL group. This relationship seems to reflect the same phenomenon as that between the PLS-Digit and DSs-age 3 . Short-term memory and language are coordinated at given points in time in normal development. However, STM does not 
predict language skills at a later time. The finding that PLS-Sentence and NSST-E are coordinated in the SELD group probably reflects the similarity in the two tasks, both involving sentence repetition. 


\section{CHAPTER $\mathrm{V}$ \\ SUMMARY AND IMPLICATIONS}

SUMMARY

Although there is agreement in the literature that memory is required for language, there is disagreement as to whether memory ability is a prerequisite for language or if language determines memory ability. The purpose of this study was to determine whether memory skills are related to language development. This question was addressed by looking at differences in memory performance between normal and SELD children, and by examining the correlation between the memory ability of a child at 3 with language ability at 3 and 4 .

This study examined the relationship between the PLSDigit and PLS-sentence memory tasks and the various expressive and receptive dependent variables. Few significant correlations were found, resulting in a failure to reject the null hypothesis of no relationship between early memory development and later language ability.

The study showed that SELD children do perform more poorly on STM and LTM tasks than do their normally speaking peers. Correlational analysis revealed that the correlations that were significant include the PLS-Digit and 
the PLS-Sentence memory recall tasks with the DSS given at the same time for the normal group, and between the PLSSentence and NSST-E given at the same time for the SELDS. This indicates a relationship exists between memory and expressive language at the same point in development. Because the relationship exists at the same age, and not across ages, these findings seem to support the theory that language and memory are related in development, but memory skill at one time does not predict language skill at another.

\section{IMPLICATIONS}

\section{Clinical Implications}

The results of this study indicate that there is insufficient evidence to suggest that memory at age 3 is correlated with language ability at age 4. However, the study does show a correlation between memory and expressive language abilities when tested at the same point in time.

This suggests that testing auditory STM skills in children with language delays will not add new information above what is learned by testing language itself. Testing auditory STM as part of a language assessment would not appear from these data to be an effecient use of the client's time.

As part of language treatment it may be beneficial to teach memory strategies to increase short-term-memory span. 
Although spontaneous use of memory strategies do not appear in the preschool child until age 5, Kail (1990) was able to teach mnemonic strategies to 3-year-olds. This would suggest that teaching strategies for increasing short-termmemory in young preschoolers with language delays may improve language learning.

Research Implications

Future research is necessary to better understand the relationship between memory and language development. The present study raises several questions which could be examined in additional studies. These questions include:

1. Are other cognitive abilities besides memory and language affected by the general maturational lag seen in the SEIDs, or are these lags specifically auditory, as the SELDs non-verbal cognitive scores on the Draw-a-Person suggest?

2. What is the correlation between memory and receptive language development?

3. What is the relationship between memory and expressive language ability between ages 3 and 4 and does this support the theory that language determines memory?

4. What is the correlation between backward-digit recall and memory development in preschool-aged children?

5. What is the correlation between memory recall ability in a naturalistic, script setting and later language ability?

6. What is the correlation between memory and language in low SES subjects?

7. Would a larger sample size affect the correlation between memory and language? 


\section{SELECTED BIBLIOGRAPHY}

Adams, Jack, A. (1976). Learning and memory: An introduction. Homewood, Ill: The Dorsey Press.

Aten, J.L. (1974). Auditory memory and auditory sequencing. Acta Symbolica, 5, 37-65.

Atkinson, R., \& Shiffin, R. (1971). The control of short term-memory. Scientific American, 225, 82-90.

Ault, R. (1983). Children's cognitive development (2nd ed.). New York: Oxford University Press.

Bayley, N. (1969). Bayley scales of infant development. New York, NY: The Psychological Corporation.

Bloom, L. and Lahey, M. (1978). Language development and language disorders. New York: John Wiley and Sons.

Boyd, T., \& Hooper, S. (1987). Substitution for estimating WISC-R verbal and full scale IQs. Perceptual and Motor skills, 65, 19-25.

Burford, S. Auditory short-term memory span and sequence for five different stimulus types, Masters Thesis, Portland State University, 1976.

Cantwel1, D., \& Baker, L. (1987). Developmental speech and language disorders. New York: The Guilford Press.

Carrow, E.C. (1974). A test using elicited imitations

in assessing grammatical structure in children. Journal of Speech and Hearing Disorders, 39, 437-442.

Carrow, E.C. (1974). Carrow elicited language inventory. Learning Concepts.

Carrow, M.A. (1972). The development of auditory comprehension of language. Austin: Learning Concepts.

Carter, E.Y. Normative data on the auditory memory test battery for age 9 through 13 years. Masters Thesis, Portland State University, 1989. 
Case, R. (1985). Intellectual development: Birth to Adulthood. Orlando: Academic Press.

Chalfant, J.C., \& Scheffelin, M.A. (1969). Central processing dysfunctions in children: A review of research. Bethesda, MD: US Department of Health, Education, and Welfare.

Chase, W., Lyon, D., \& Ericsson (1984). Individual differences in memory span. In Morton Friedman, J.P. Das and Neil O'Connor (Eds.), Intelligence and learning. New York: Plerium Press.

Chi, Michelene (1976). Short-term memory limitations in children: capacity or processing deficits? Memory and Cognition, 4, 559-572.

Clarke-stewart, A., Perlmutter, M., \& Freidman, S. (1988).

Lifelong human development. New York: John Wiley \& Sons.

Cofer, C.N. (1976). The structure of human memory. San Francisco: W.H. Freeman and Co.

Davis, P.R. Normative data on the auditory memory performance of three and four-year old children as measured by the auditory memory test package (AMTP).

Masters Thesis, Portland State University, 1984.

Faas, L.A. (1980). Children with learning problems: A Handbook for teachers. Boston: Houghton Mifflin.

Flavel1, J. (1985). Cognitive development. Englewood Cliffs, New Jersey: Prentice-Hall.

Flowers, A. (1983). Auditory perception: Speech, language and learning. Dearborn, MI.: Perceptual Learning Systems.

Gardner, M.F. (1985). Test of auditory-perceptual skills. San Francisco: Children's Hospital of San Francisco.

Gerber, A. (1981). Problems in the processing and use of language in education. In Adele Gerber and Diane Bryen (Eds.), Language and learning disabilities (pp. 75112): Baltimore: University Park Press.

Goodenough, H. \& Harris, D. (1963). Draw-a-person test. New York, NY: Harcourt, Brace and Jabonobich. 
Harris, D. (1963). Children's drawings as measures of World, Inc.

Hulme, C., Thomson, N., Muir, C., \& Lawrence, A. (1984). Speech rate and the development of short-term-memory span. Journal of Experimental Child Psychology, 38, 241-253.

Hutterlocher, J., \& Burke, D. (1976). Why does memory span increase with age? Cognitive Psychology, 8, $1-31$.

Heasley, B.E. (1974). Auditory perceptual disorders and remediation. Springfield, ILL: Charles C. Thomas.

Kail, R. (1990). The development of memory in children (3rd ed.). New York: W.H. Freeman \& Co.

Labenz, P.J., \& Fay, W.H. (1980). Auditory memory. In P.J. LaBenz and E.S. LaBenz (Eds.), Early correlates of speech, language and hearing. Littleton, Mass.: PSG Publishing.

Lahey, M. (1988). Language disorders and language development (2nd ed). New York: MacMillan.

Lee, L. (1971). Northwestern syntax screening test.

Evanston: Northwestern University Press.

Lee, L. (1974). Developmental sentence analysis. Evanston, Ill.: Northwestern University Press.

Lerner, J.W. (1971). Children with learning disabilities: Theories, diagnosis, and teaching strategies. Boston: Houghton Mifflin.

Masland, M., \& Case, L. (1968). Limitation of auditory memory as a factor in delayed language development. Bristish Journal of Disorders in Communication, 3, 139142 .

Mecham, M.J., \& Willbrand, M.L. (1979). Language disorders in children. Springfield, Ill: charles C. Thomas.

Meyers, J.K., \& Bean, L.C. (1965). A decade later: A follow-up of social class and mental illness. New York, NY: Wyley and Sons. 
Mountain, M.C. (1980). Normative data on the auditory memory test battery. Masters Thesis, Portland state University, 1980 .

Newcomer, P.I., \& Hammill, D.D. (1977). Test of language development. Austin: Pro-Ed.

Nicolson, R. (1984). The relationship between memory span and processing speech. In Morton Friedman, J.P. Das, \& Neil O'Connor (Eds.), Intelligence and learning.

New York: Plenum Press.

Olson, G.M. (1973). Developmental changes in memory and the acquisition of language. In $T$. Moore (Ed.)

Cognitive development and the acquisition of language, (pp. 145-157). New York: Academic Press.

ornstein, P.A. (1978). Memory development in children. Hillsdale, New Jersey: Lawrence Erlbaum.

Paul, R. (1991). Profile of toddlers with slow expressive language development. Top Language Disorders, 11(4), $1-13$.

Rescorla, L. (1989). Language development survey: A screening tool for delayed language in toddlers." Journal of Speech and Hearing Disorders, 54, 587-599.

Rosenblum, E.H. (1979). Fundamentals of hearing for health professionals. Boston: Little, Brown and Company.

Schofield, N., \& Ashman, A. (1986). The relationship between digit span and cognitive processing across ability groups. Intelligence, 10, 59-73.

Speidel, G.E. (1989). Imitation: A bootstrap for learning to speak? In G.E. Speidel \& R.E. Nelson (Eds.) The many faces of imitation in language learning (pp. 151179). New York: Springer-verlag.

Speidel, G.E., \& Herrsshoff, M.J. (1989). Imitation and the construction of long utterances. In G.E. Speidel and K.E. Nelson (Eds.) The many faces of imitation in language learning, (pp. 181-197). New York:

Springer-Verlag.

Spitz, H.H. (1972). Note on immediate memory for digits: Invariance over the years. Psychological Bulletin, $78,183-185$. 
Torgesen, J. (1990). Studies of children with learning disabilities who perform poorly on memory span tasks. In Joseph Torgesen (Ed.) Cognitive and behavior characteristics of children with learning disabilities. Austin: Pro-ed.

Wallace, G., \& McLoughlin, J.A. (1988). Learning disabilities: Concepts and characteristics. Columbus, OH.: Merrill Publishing.

Wepman, J.M., \& Morency, A. (1973). A manual of administration, scoring and interpretation: The auditory sequential memory test. Palm springs: Language Research.

Wiig, E.H., \& Semel, E.M. (1984). Language and intervention for the learning disabled. Columbus: $\overline{B e l} 1$ and Howell.

Wiig, E.H., \& Semel, E.M. (1976). Language disabilities in children and adolescents. Columbus, OH.: Charles E. Merrill.

Witkin, B. (1971). Auditory perception-implications for language development. Language speech and Hearing Services in the Schools, $8,140-154$.

Young, E. (1984). A review of general language performance tests for preschool children. Topics in Early Childhood Special Education, 4, 100-111.

Zimmerman, I.L., Steiner, V.G., \& Pond, R.E. (1979). Preschool language scale manual- Revised. Columbus, OH: Charles E. Merrill. 
APPENDIX A

PARENT CONSENT FORM 
COLLEGE OF

LIBERAL ARTS ANO SCIENCES

SHEECHAND

HEARINC SCIENCES

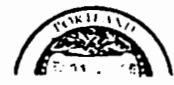

\author{
PORTLANO \\ STATE \\ UNIVFRSITY
}

97207

$503 / 229.3531$

Dear Parents,

We would like to invite you and your child to participate in a study of language development in toddlers. We hope to learn more about the age range that is normal for the beginning of speech and how children communicate in other ways during the toddler period. If you agree to join the study, you will be asked to bring your child to PSU for testing sessions every 5-12

months. At each session the child will be videotaped playing with you and some toys. We will ask the child to identify some pictures and act out some

instructions with toys (such as "Push the car.") In addition we will ask you to answer some questions about the child's social and self-help sk!lls. All parents participating will receive counseling and a list of suggestions for fostering language growth in children under three years of age. The potential benefits of the study are some help for you with stimulating language in your child. In addition, any child who reaches age three and appears to be having problems with language-learning can be referred for services in our clinic or elsewhere.

If you decide not to participate, of course the services you receive from your child's pediatrician, PSU, or any other agency will not be affected. If you decide to join the study you may withdraw at any time.

All results of your child's evaluations will remain strictly confidential. However, if you would like them to be communicated to your pediatrician or anyone else, we will be glad to do so. There will be no charge for any work done with you or your child as part of this study.

If you have any questions, please do not hesitate to ask them, or to call me at 229-3533. Thank you for your help.

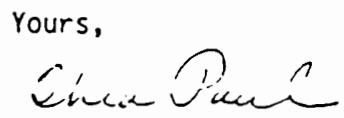

Rhea Paul, Ph.D., CCC-SPL

Assistant Professor

I (do) (do not) give permission for my child,

to participate in the study described above.

I (do) (do not) give permission to show my child's videotapes for teaching or professional presentations only. I realize full names will not be used in any such presentations. 


\section{APPENDIX B}

PRESCHOOL LANGUAGE SCALE 


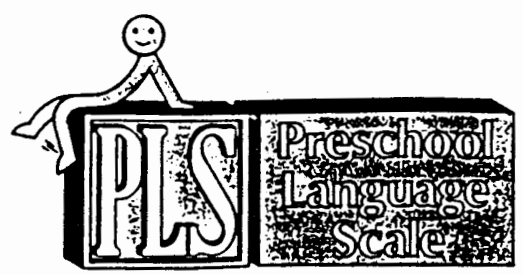

\section{Record Form}

\section{Revised Edition}

Irla Lee Zimmerman, Violette G. Steiner, \& Roberta Evatt Pond

Materials needed to administer test:

Preschool Language Scale manual

Preschool Language Scale picture book

121 " colored blocks in box (red, yellow, blue, green, orange, purple)

Small piece of coarse sandpaper

Set of coins: half-dollar, quarter, dime, nickel, penny

Watch or clock with second hand

\section{Auditory Comprehension:}

Point Score

AC Age

ACQ

Verbal Ability:

Point Score

VA Age —

VAQ

Language Age

$$
\frac{\mathrm{LQ}}{\mathrm{ACQ}+\mathrm{VAQ}}=\mathrm{LQ}
$$

$\frac{A C+V A}{2}=L A$

Name

School

Teacher

Parent or guardian

City State

Examiner

$$
\text { Yr. Mo. Day }
$$

Date administered

Birthdate

Chronological age

Charles E. Merrill Publishing Co.

A Bell \& Howell Company

Columbus. Ohio 43216

Copyright (C) 1979, 1969 by Bell \& Howell Co. All rights reserved. 
ory Comprehension

Understands the Concept of "One"

(Twelve blocks.)

Must hand examiner only one block.

Compares Size

Piciure Book plate 6, p. 12.)

Show me the tiny, little spoon.

Undersiands Use

(Picture Book, plate 7, p. 14)

(Same as item 15: administer only once)

Show me what a we use to comb our hair b. we use to

drink our milk_, c. goes on our feet_, d. we ride on

e. we use to iron clothes_, f. we can cut with__, 8. we use

10 sweep the

Follows Simple Commands

(Twelve blocks, box.)

a. Make a tower like this

bow, let's make a irain

c. Now, put the blocks in the box.

(Passes two.)

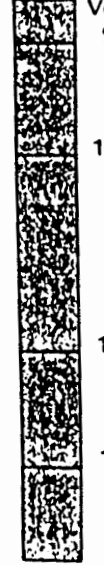

Verbal Ability

Repeats Two Digits

Listen: say 2.

b. $5-8 \ldots$, c. $3-9$

(Passes one.)

10. Names Objects

(Same as item 6; administer only once.)

What is that?

a shoe b. watch c. table

d. ball chair

g. pencil_, h. floor

(Passes five.)

1. Repeats Sentences

Can you say, I am blg boy (gifl) ? a. I like to play in the water-

b. I have a little dog__, c. The dog chases the cat

(Repeats one sentence.)

2. Articulates Consonanis

(See page 7 in this record form booklet.)

Administer all articulation items at same time. Child passes it

correctly pronounces consonants in Group I.)

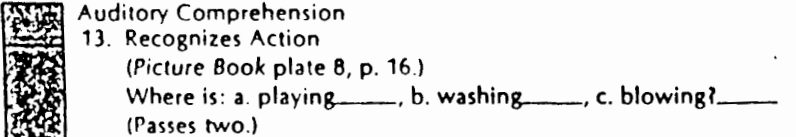

TPasses two.

. Distinguishes Prepositions (One block.)

(Same as itern 22; administer only once)

ut the block: $a$. on the chair_, b. under the chair c in fron of the chair
(Passes iwo.)

15. Undersiands Use

(Piclure Book, plate 7, p. 14

Same as item 11; administer anly once.

Show me what: $a$. we use to comb our hair__, b. we use to

we ride on use

e. we use to iron clothes__ $f$. we can Cul with___, B. We use to sweep the lloor

16. Distinguishes Parts

(Piclure Book plate 9, p. 18)

the train

$c$. tail of the horse d. nose of the cow

(Passes three.)

\section{SECTION V: 3 years to 3 years 6 months}

Auditory Comprehension

17. Recognizes Time

17. Gives Full Name

13. Repeats Three Digits
Listen. Say 4-2.
Now say: a. 1-4-9_, b. 9-6-1_, c. $2-5-3$ _

Now say: a. 1-4-9.

(Passes one.)

(Picture Book plate 10, p. 20 .)

What is this? (a. shoes , b. blocks___, c. socks

d. bananas

(Passes two.)

15. Comprehends Physical Need

(Same as item 19 and item 23; administer only once.)

c. cold?

16. Converses in Sentences

Tell me about your pets. (on) Tell me about your toys (sister, baby)

(Uses two or more four- to five-word sentences to answer.) 
18. Comp correclly on hist louch.

(Picture Book plate

Show me the long one. Put your finger on the long IIne.

(Six trials, alternating position of plate.)
-
b.
c.
d.
e. $1=$
i. 1
Passes three out of the first three or five out of six.
Matches Sels
(Twelve blocks.)
Make yours like mine.
Malches: a. 1__, b. 4 _ c. 2
(Passes three.)
20. Groups Objects
Picture Book plate 13, p. 26.
Show me: 2 . all the animals_ b. all the things we eal
(Passes two; points to three in each group.)

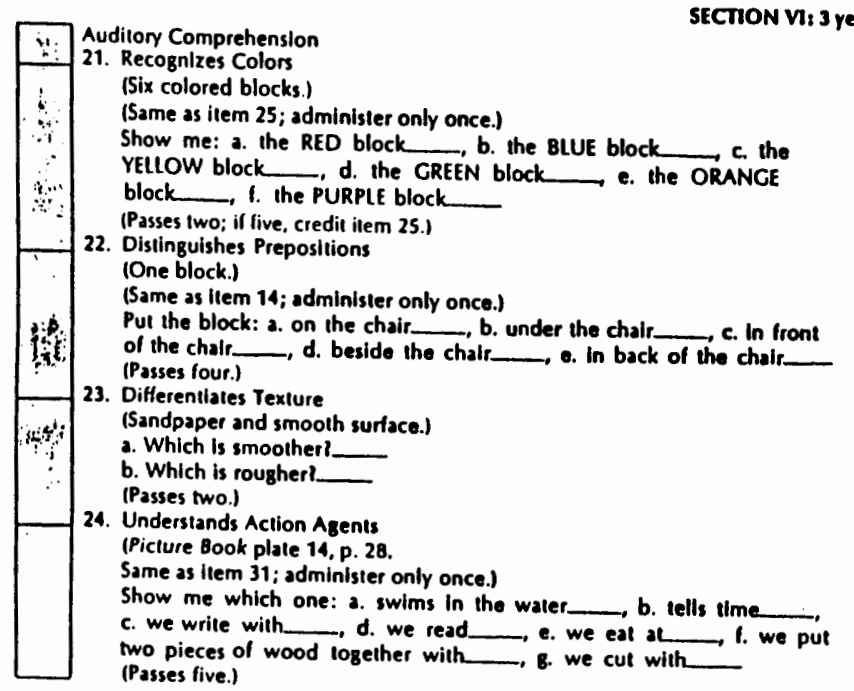
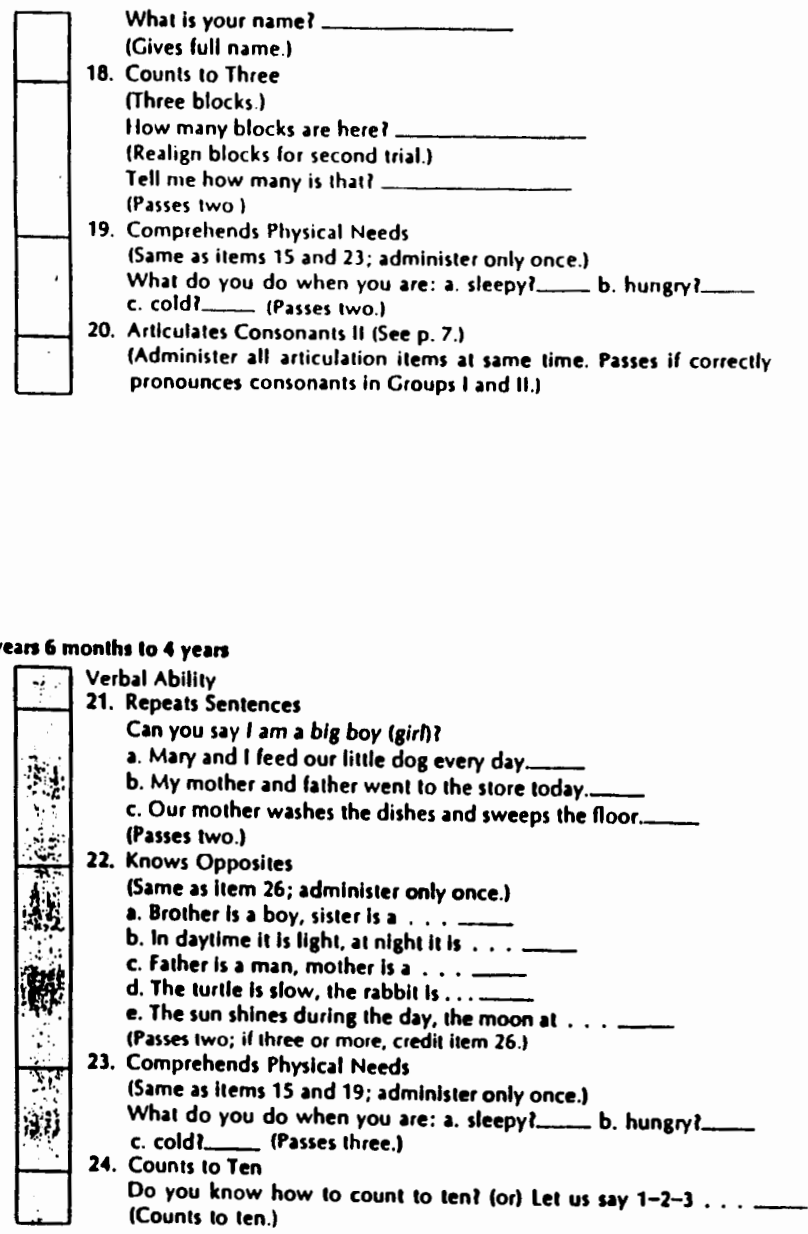
(Passes five.) 
APPENDIX C

NORTHWESTERN SYNTAX SCREENING TEST 
NORTHWESTEEN STMTAX SCREDING TEST RECORD FORM

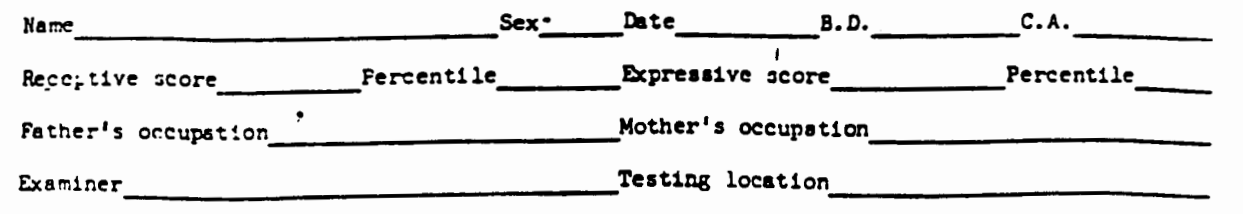

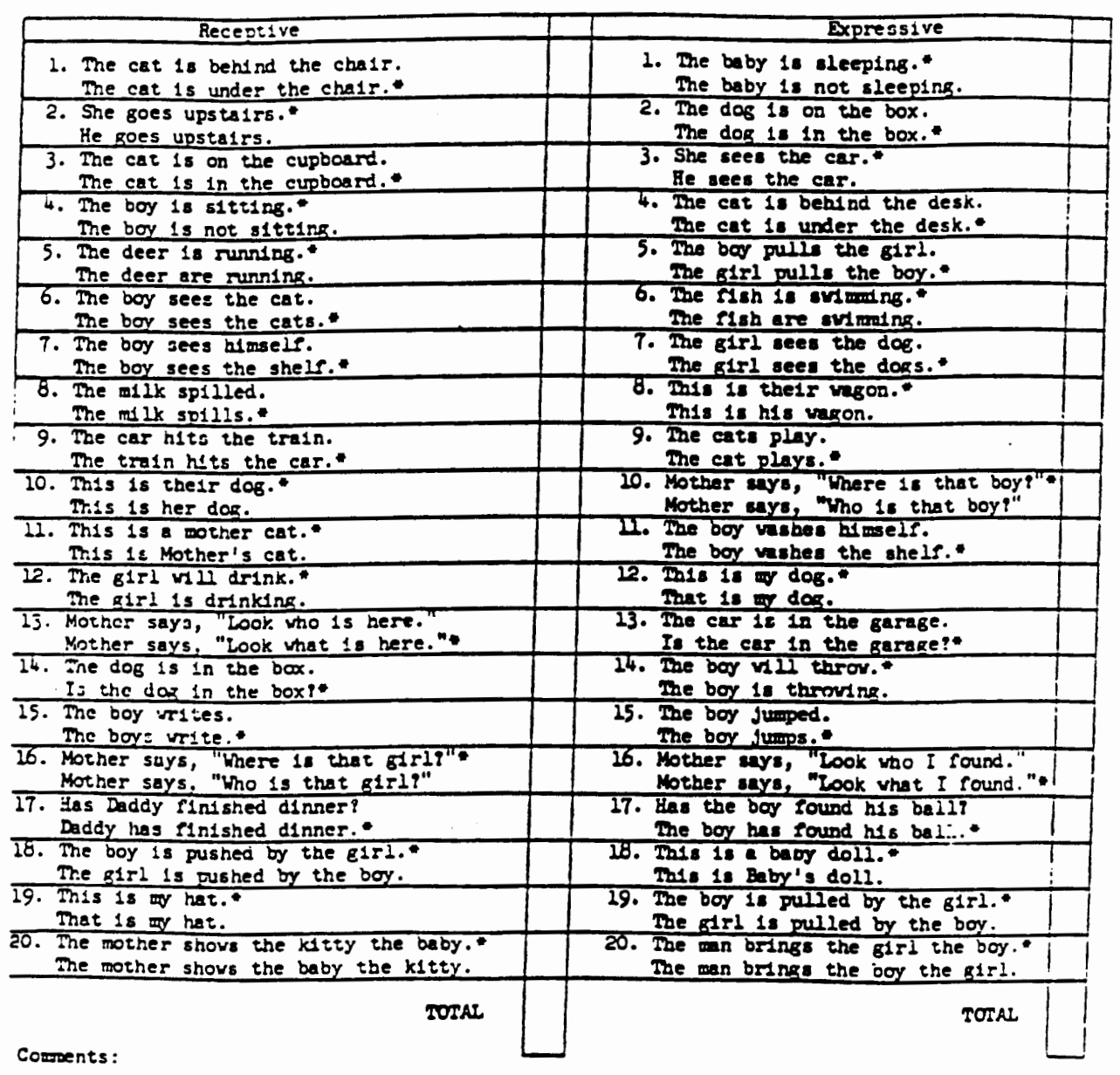


APPENDIX D

TEST OF AUDITORY COMPREHENSION OF LANGUAGE-REVISED 


TACL-R
INDIVIDUAL
RECORD FORM

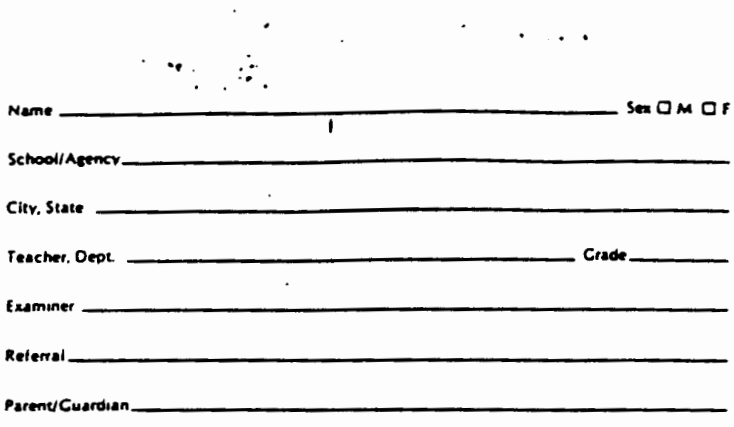

Address

Street

CItr. Sute. Zip

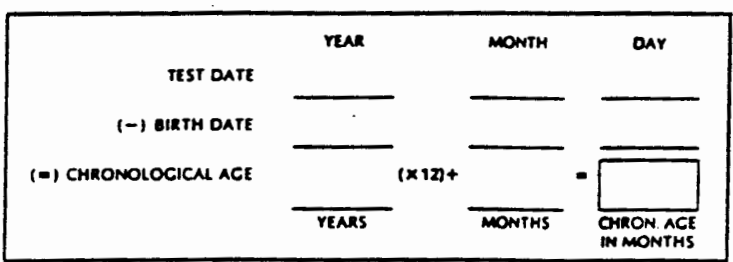

\begin{tabular}{|c|c|c|c|c|c|c|c|c|}
\hline \multirow[t]{3}{*}{$\begin{array}{l}\text { SCORE } \\
\text { SUMMARY }\end{array}$} & \multirow{2}{*}{\multicolumn{2}{|c|}{$\begin{array}{l}\text { 1. WORD CLASSES } \\
\text { AND REUTIONS } \\
\text { RAW } \\
\text { SCORE }\end{array}$}} & \multirow{2}{*}{\multicolumn{2}{|c|}{$\begin{array}{l}\text { I1. GRAMMATICAL } \\
\text { MORPHEMES } \\
\text { SCORE }\end{array}$}} & \multicolumn{2}{|c|}{$\begin{array}{l}\text { III. ELABORATED } \\
\text { SENTENCES }\end{array}$} & \multicolumn{2}{|c|}{$\begin{array}{l}\text { IV. TOTAL Sr.ORE } \\
\text { men keans }\end{array}$} \\
\hline & & & & & SCORE & & SCORE & \\
\hline & $\begin{array}{l}\text { ACE } \\
\text { IFVEL } \\
\text { SCORES }\end{array}$ & $\begin{array}{l}\text { GUDE } \\
\text { WNEL } \\
\text { SCORES }\end{array}$ & $\begin{array}{l}\text { AGE } \\
\text { LEVEL } \\
\text { SCORES }\end{array}$ & $\begin{array}{l}\text { CRUOR } \\
\text { INLL } \\
\text { SCORES }\end{array}$ & $\begin{array}{l}\text { ACE } \\
\text { IEVEL } \\
\text { ScORES }\end{array}$ & $\begin{array}{l}\text { CuOE } \\
\text { invi } \\
\text { Scores }\end{array}$ & $\begin{array}{l}\text { AGE } \\
\text { LERL } \\
\text { SCORES } \\
\end{array}$ & $\begin{array}{l}\text { GNOE } \\
\text { GNEI } \\
\text { SCORES }\end{array}$ \\
\hline \multicolumn{9}{|l|}{ PERCENTILE RANK } \\
\hline $\begin{array}{l}\text { S̄ANDARO SCORE (SS) } \\
\text { Circte One: \& T DO NCE }\end{array}$ & and 1 & wean? & naed 1 & new 2 & wens & $\operatorname{loc} 2$ & hant & aves \\
\hline $\begin{array}{l}\text { SMNOARO ERROR OF } \\
\text { MEASUREMENT ISEMI }\end{array}$ & \multicolumn{2}{|c|}{ Dous } & \multicolumn{2}{|c|}{ wants } & \multicolumn{2}{|c|}{ and } & \multicolumn{2}{|c|}{$\operatorname{sen} 13$} \\
\hline $\begin{array}{l}\text { CONFIOENCE INTERVAL } \\
\text { I - ANO + I SEMI }\end{array}$ & wans. & ines & $\begin{array}{r}-\infty \\
-\infty-10 \\
\end{array}$ & $\begin{array}{c}-\infty \\
-\infty\end{array}$ & $\begin{array}{c}\text { waes } \\
-\infty\end{array}$ & $\begin{array}{r}0 \text { ans } \\
\end{array}$ & wen. & ons \\
\hline $\begin{array}{l}\text { ACE EQUTMLENTSCORES } \\
\text { 1 - ANO - I SEMI }\end{array}$ & & & & & & & & \\
\hline \multirow[t]{2}{*}{$\begin{array}{l}\text { WOEX NUMBER (for norn } \\
\text { normalixed koons onivi }\end{array}$} & wenct & & andit. & & went: & & Tas. & \\
\hline & $=1$ & $N+1$ & $\mathrm{Na}$ & and & $\operatorname{mat}$ & Ni: & $\pi 4$ & me \\
\hline
\end{tabular}

Norts 


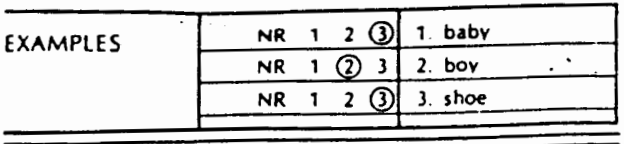

Section I. WORD CLASSES AND RELATIONS

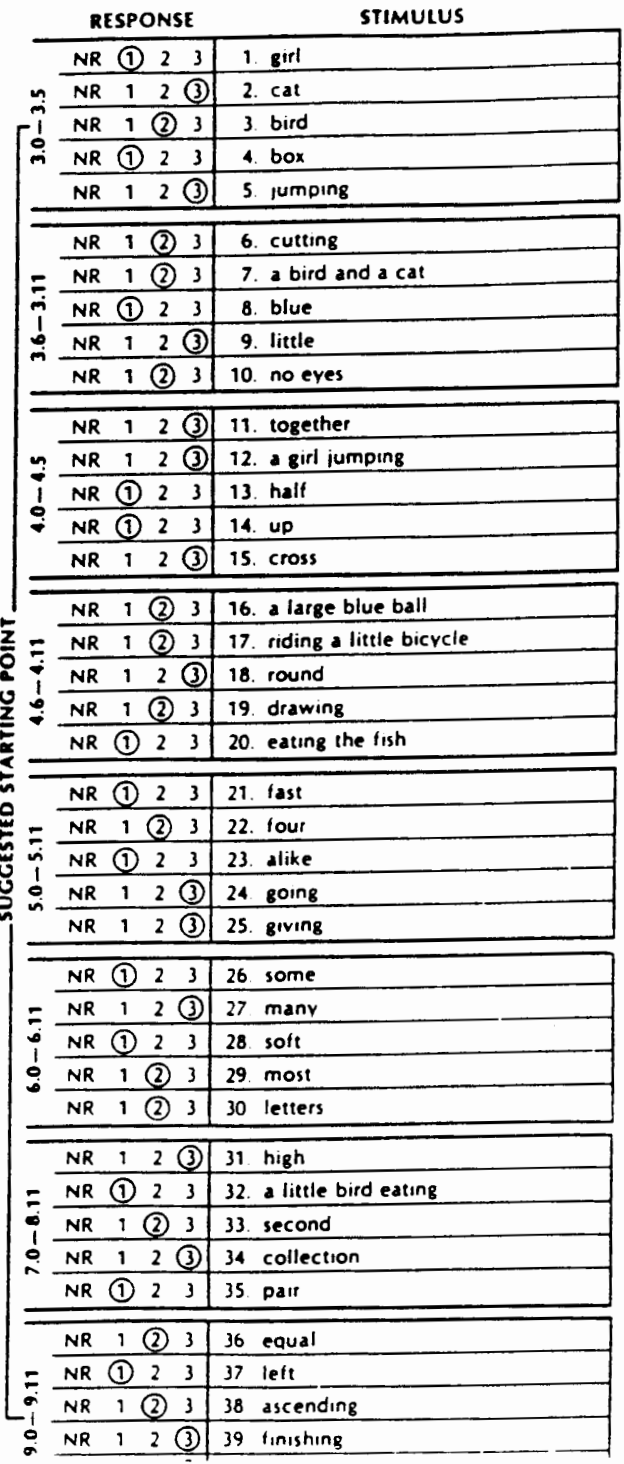

basal ano CeILINC RULES

BASAL: Four (4) consecutive correct at an age level. CEILINC: Three (3) consecutive incorrect

\section{Section II. GRAMMATICAL MORPHEMES}

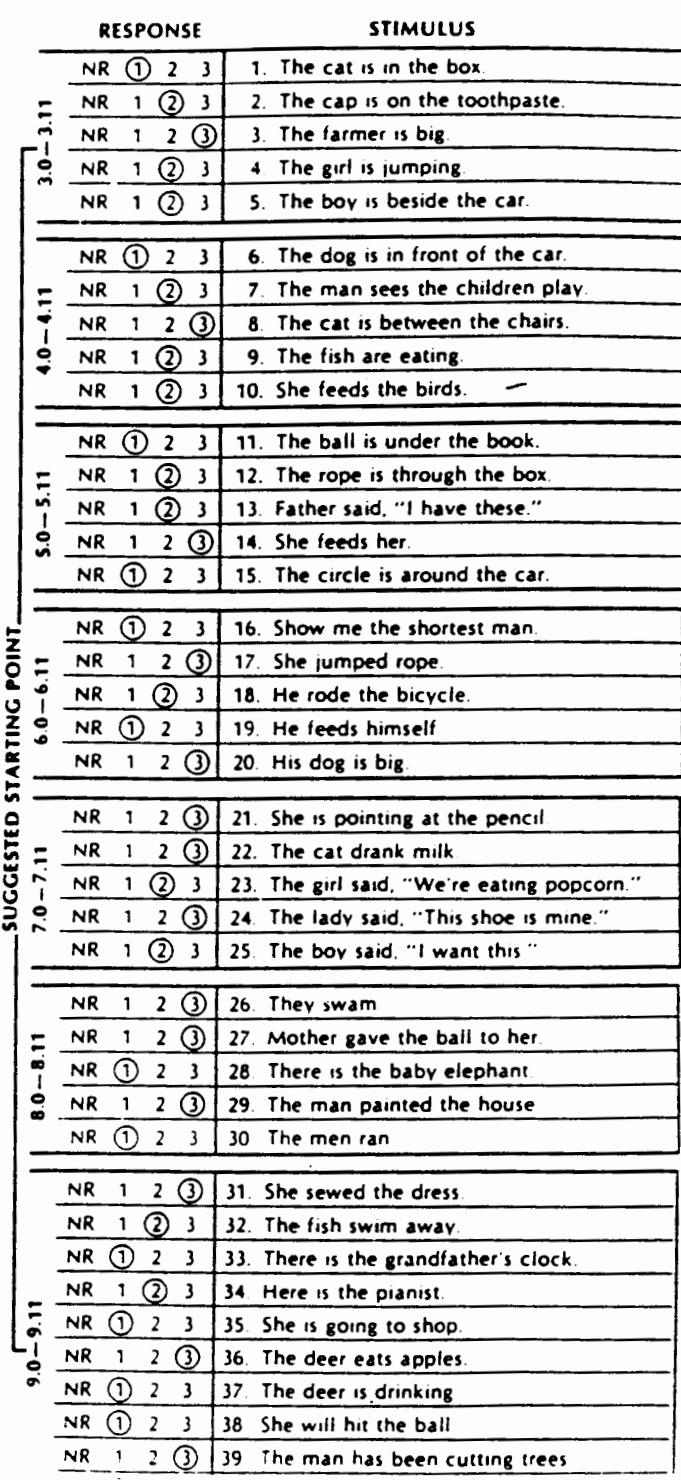




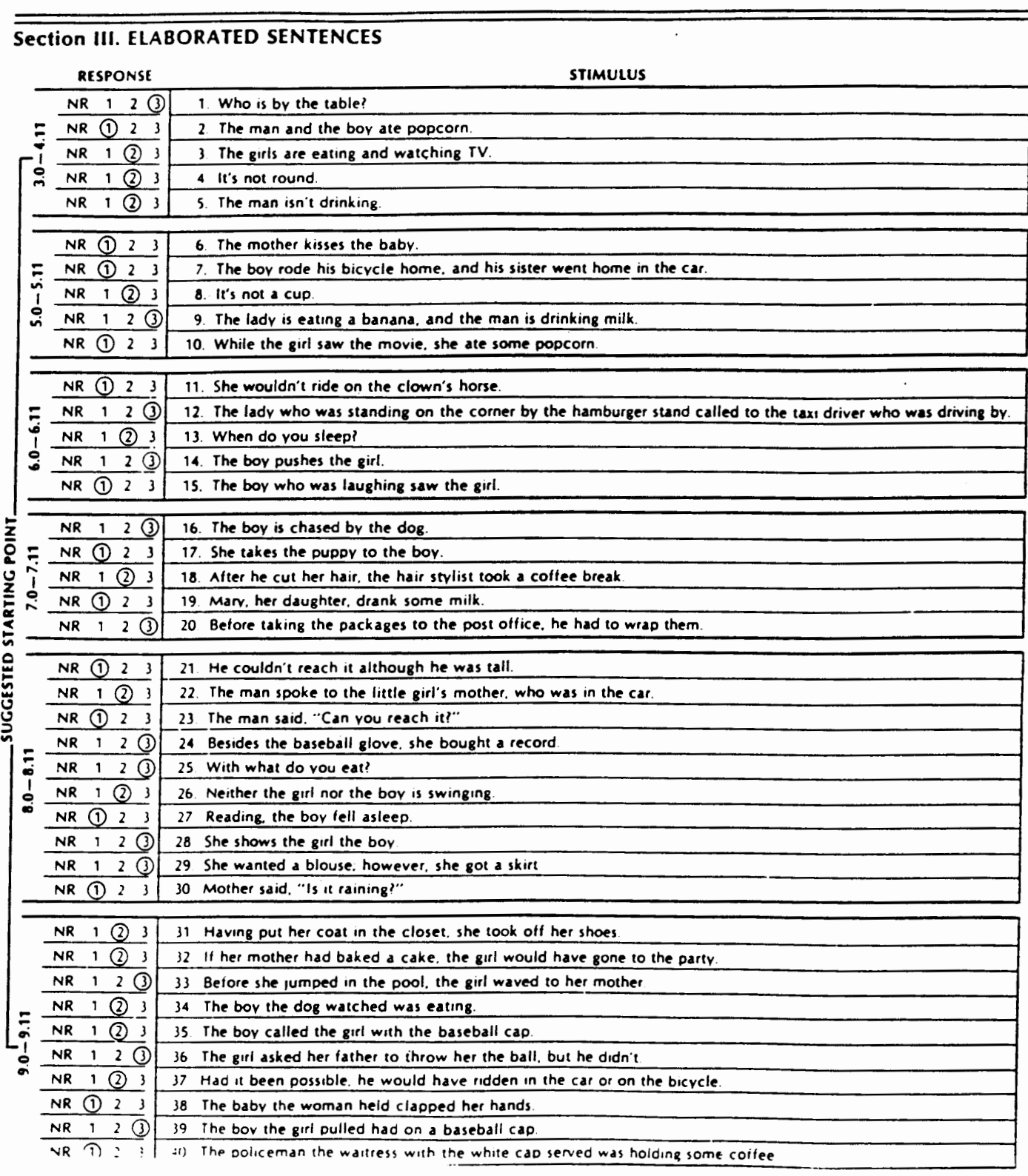



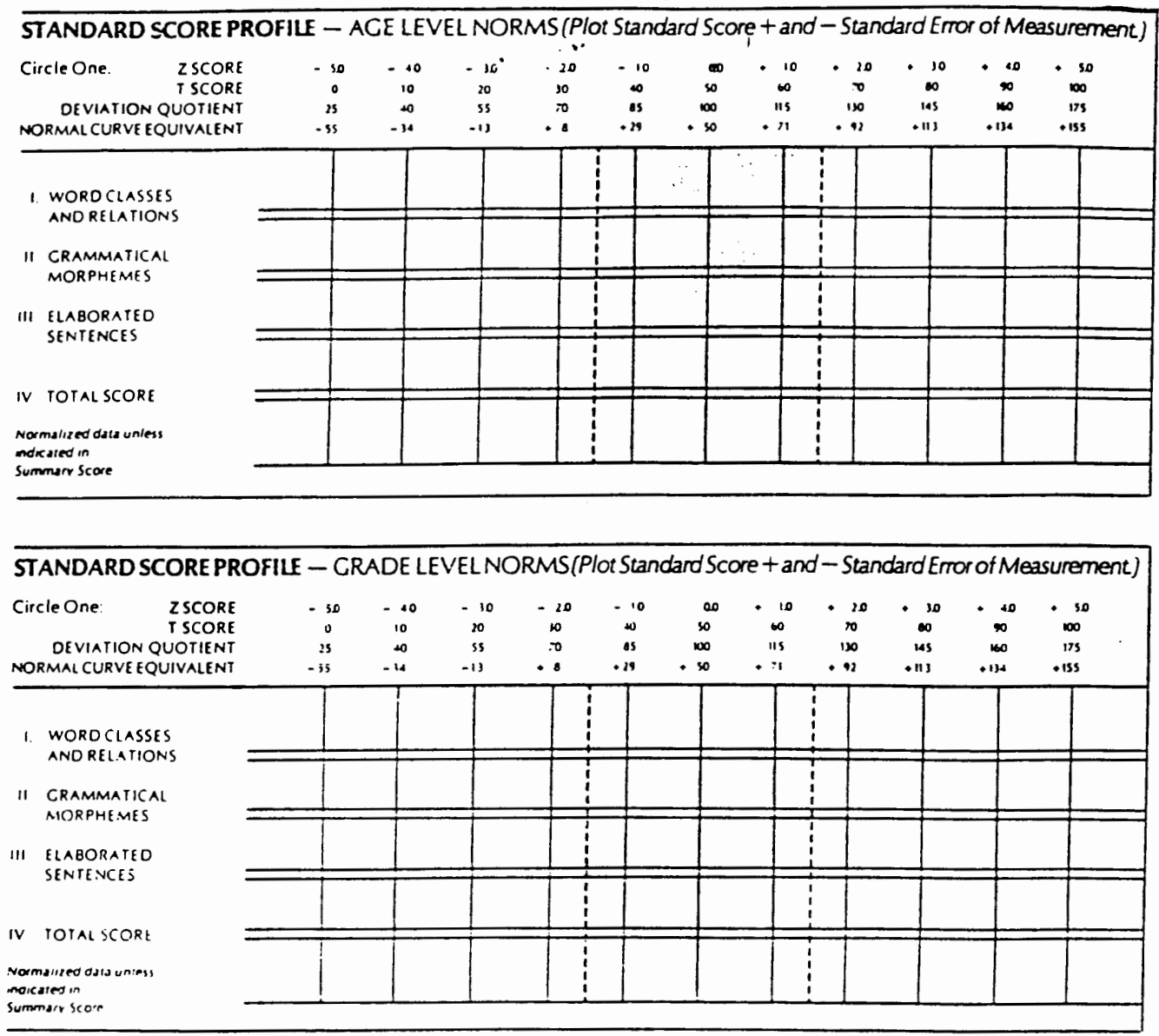

\section{AGE EQU:VALENT SCORE PROFILE}

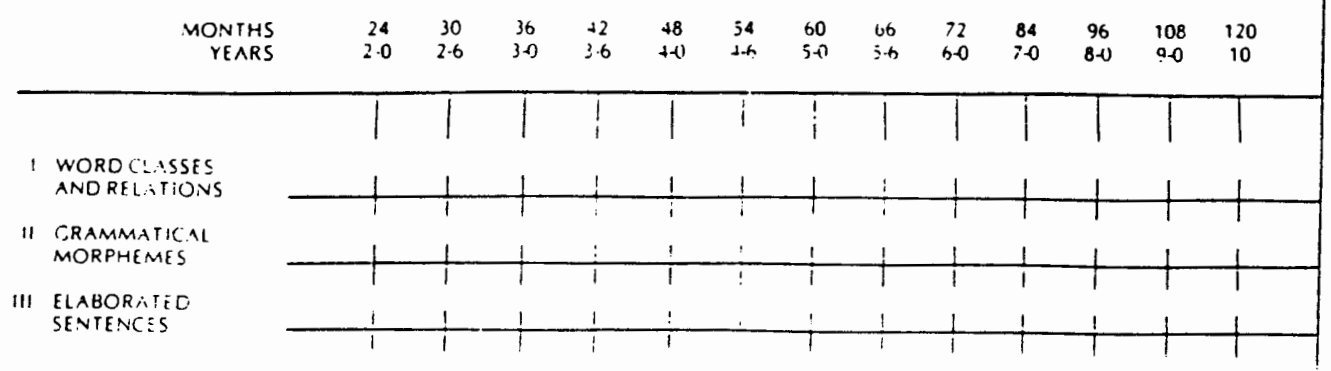


APPENDIX E

DEVELOPMENTAL SENTENCE SCORING 


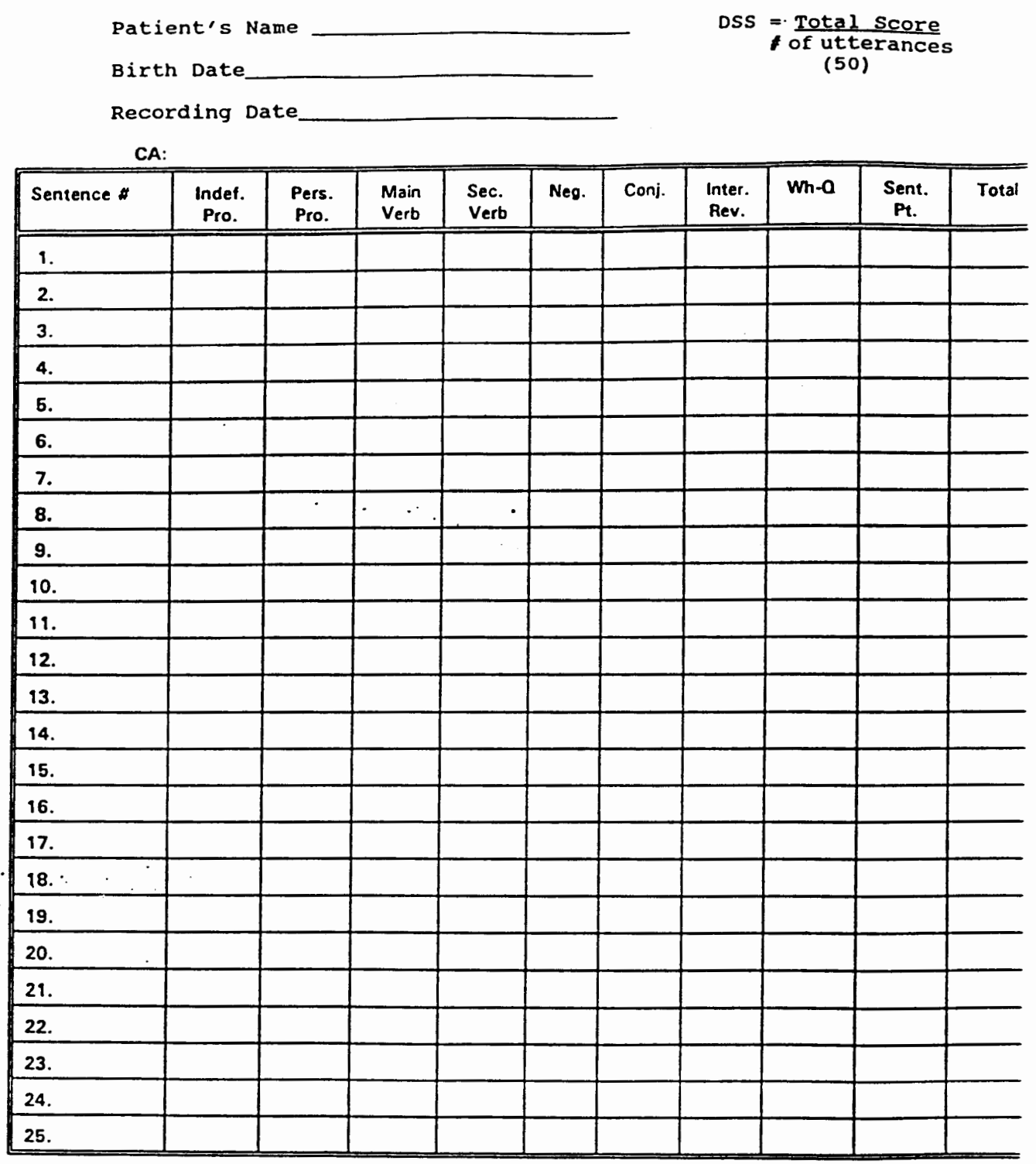


APPENDIX F

TEST OF LANGUAGE DEVELOPMENT- PRIMARY 
TOLD-P

TEST OF LANGUAGE DEVELOPMENT PRIMARY

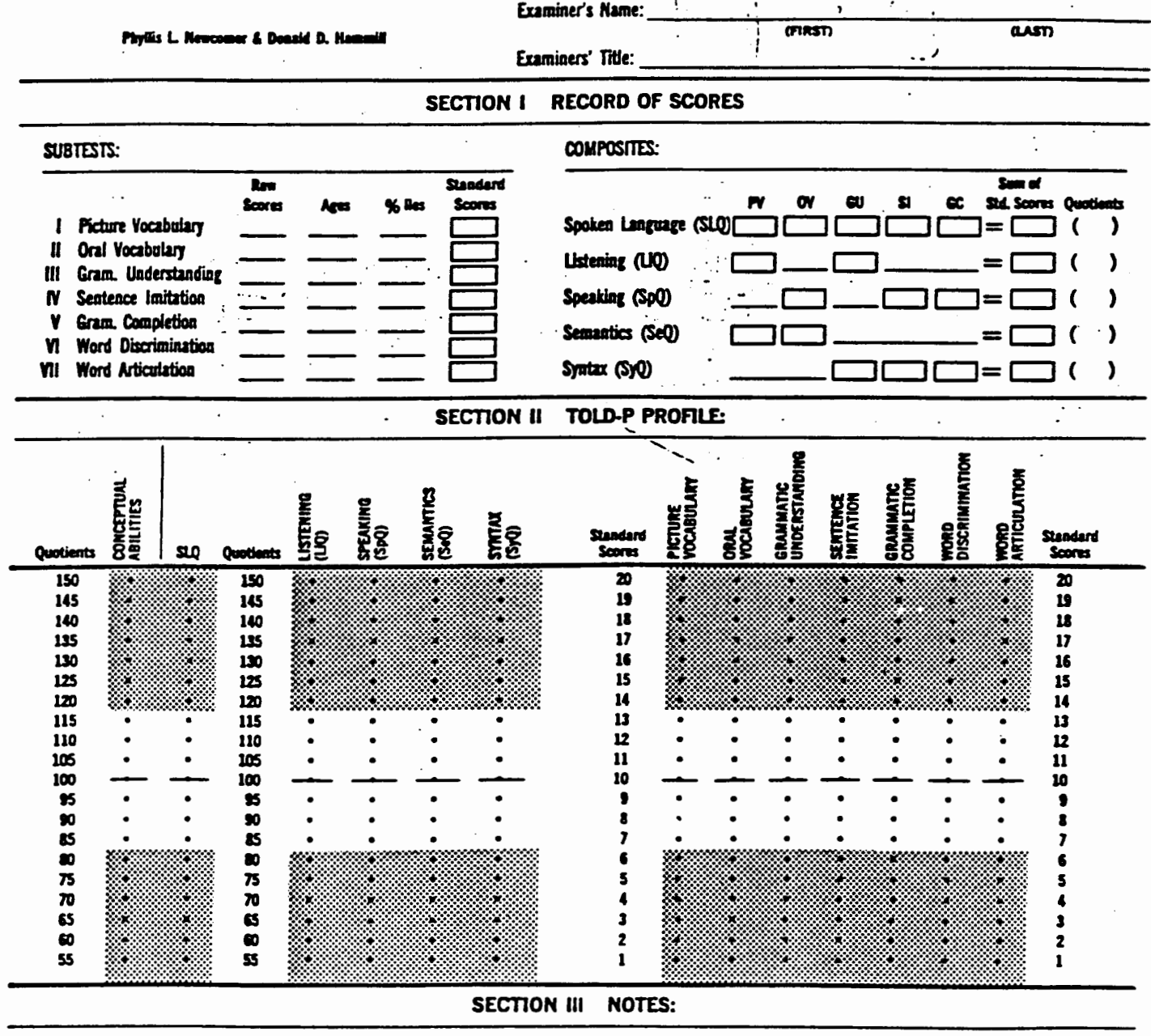

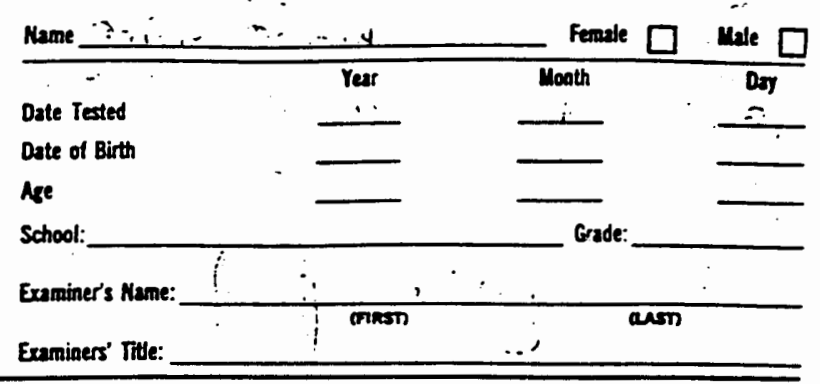

muposmes:

Spoken Languge SLL $\square \square \square \square \square=\square($ )

Utstening (UD) . : $\square \square \square=\square($ )

Speckiliag SPDE : $=\square-\square \square=\square($ )

Sematios (seo) $\square \square \square($, )

$$
\text { . }
$$




\begin{tabular}{|c|c|c|c|}
\hline $\begin{array}{l}\text { PICTURE } \\
\text { VOCABLLARY }\end{array}$ & $\begin{array}{l}\text { Seore } \\
1 \text { or } 0\end{array}$ & $\begin{array}{l}\text { Discontinue attor } 5 \\
\text { consecutive flltures }\end{array}$ & $\begin{array}{l}\text { score } \\
100\end{array}$ \\
\hline 1. mirror & 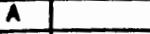 & 16. entiprent C & 1 \\
\hline 2. bulb & $\bar{A}$ & 17. vine & \\
\hline 3. tray & $\bar{A}$ & 18. monument 8 & \\
\hline 4. tarmer & T & 79. herd & \\
\hline 5. anchor & $\bar{A}$ & 20. noved & \\
\hline 6. explosive & $\overline{8}$ & 21.100610 & \\
\hline 7. lizard & 8 & 22. dome & \\
\hline 8. whinged & $\bar{A}$ & 23. phoral & \\
\hline 9. stump & $\overline{8}$ & 24. matomal $A$ & \\
\hline 10. medical & 8 & 25. intanty D & \\
\hline 11. young & C & \multirow{5}{*}{\multicolumn{2}{|c|}{$\begin{array}{l}\text { Ho. of is } \\
\text { Ho. of } 05 \\
\text { Tot }\end{array}$}} \\
\hline 12. royage & 8 & & \\
\hline 13. woep & $\bar{C}$ & & \\
\hline 14. samon & $\bar{A}$ & & \\
\hline 15. कi & $\bar{A}$ & & \\
\hline
\end{tabular}

\begin{tabular}{|c|c|c|}
\hline ORAL VOCABULARY & Descontinue ation 5 consecutive talliris & $\begin{array}{l}\text { score } \\
1 \text { or } 0\end{array}$ \\
\hline 1.0ind & . & 1 \\
\hline 2. nest & & 2 \\
\hline 3. tace & $\because$ & 3 \\
\hline 4. door & $\because$ & 4 \\
\hline 5. cow & & $\because$ \\
\hline 6. finger & 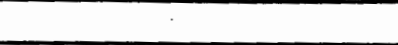 & 6 \\
\hline 7. ocean & & 7 \\
\hline 8. supar & & 8 \\
\hline 9. Iorest & & $\overline{9}$ \\
\hline 10. baby & & 10 \\
\hline 11. poor & & 11 \\
\hline 12. sad & & 12 \\
\hline 13. soason & & 13 \\
\hline 14. castle & & 14 \\
\hline 15.010 & & 75 \\
\hline 16. true & & 16 \\
\hline 17. benind & & 17 \\
\hline 18. village & . & $\overline{18}$ \\
\hline 19. all & & 19 \\
\hline 20. north & & $\overline{20}$ \\
\hline
\end{tabular}




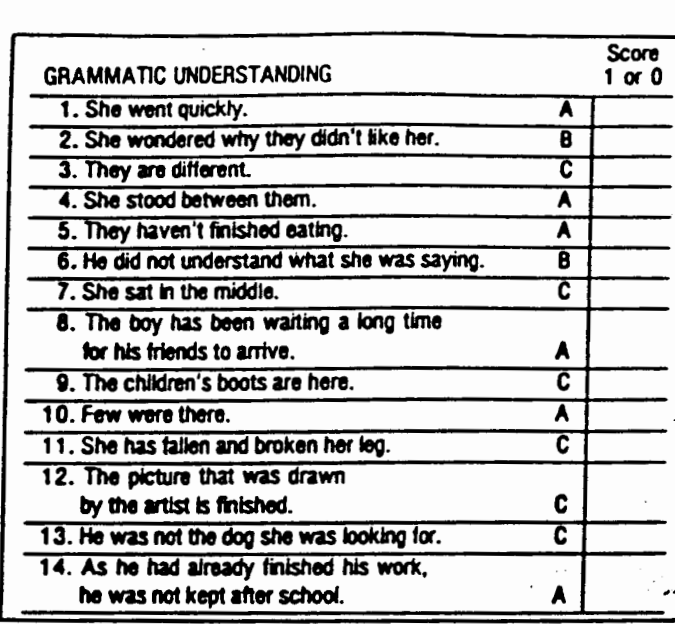

\begin{tabular}{|c|c|c|}
\hline $\begin{array}{l}\text { Ossconthue ather } 5 \\
\text { consecutivo failures }\end{array}$ & & $\begin{array}{l}\text { Score } \\
\text { or } 0\end{array}$ \\
\hline 15. It goes up. $-\cdots \cdots$ & $\mathbf{C}$ & $\therefore$ \\
\hline $\begin{array}{l}\text { 16. Having heard the ovidence, the juds } \\
\text { sentenced him. }\end{array}$ & C & \\
\hline 17. He is going to pltch. $\quad \ldots$ i .. & 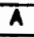 & \\
\hline 18. Neither the girafie nor the lion is rumn & $\mathbf{C}$ & \\
\hline 18. Ho had ndoden. $\therefore, \ldots, \ldots$ and. & $\mathbf{C}$ & \\
\hline $\begin{array}{l}\text { 20. The boy who is wearing the } \\
\text { checkered sweater is the whiner. }\end{array}$ & C & \\
\hline 21. The paper fred boen delivered. & $\bar{A}$ & \\
\hline 22. The dog belonged to the other boy. & $\bar{A}$ & \\
\hline 23. The bad boy had eaten it all & $\mathbf{C}$ & \\
\hline 24. Ho ss the one to do the final pr & B & \\
\hline 25. The bicycle fad been stolen. & $\mathbf{C}$ & \\
\hline
\end{tabular}
25. The bicycle fad been stolen.

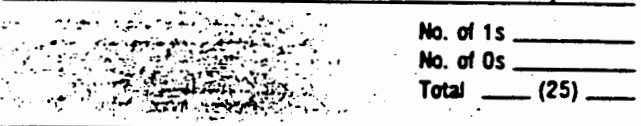

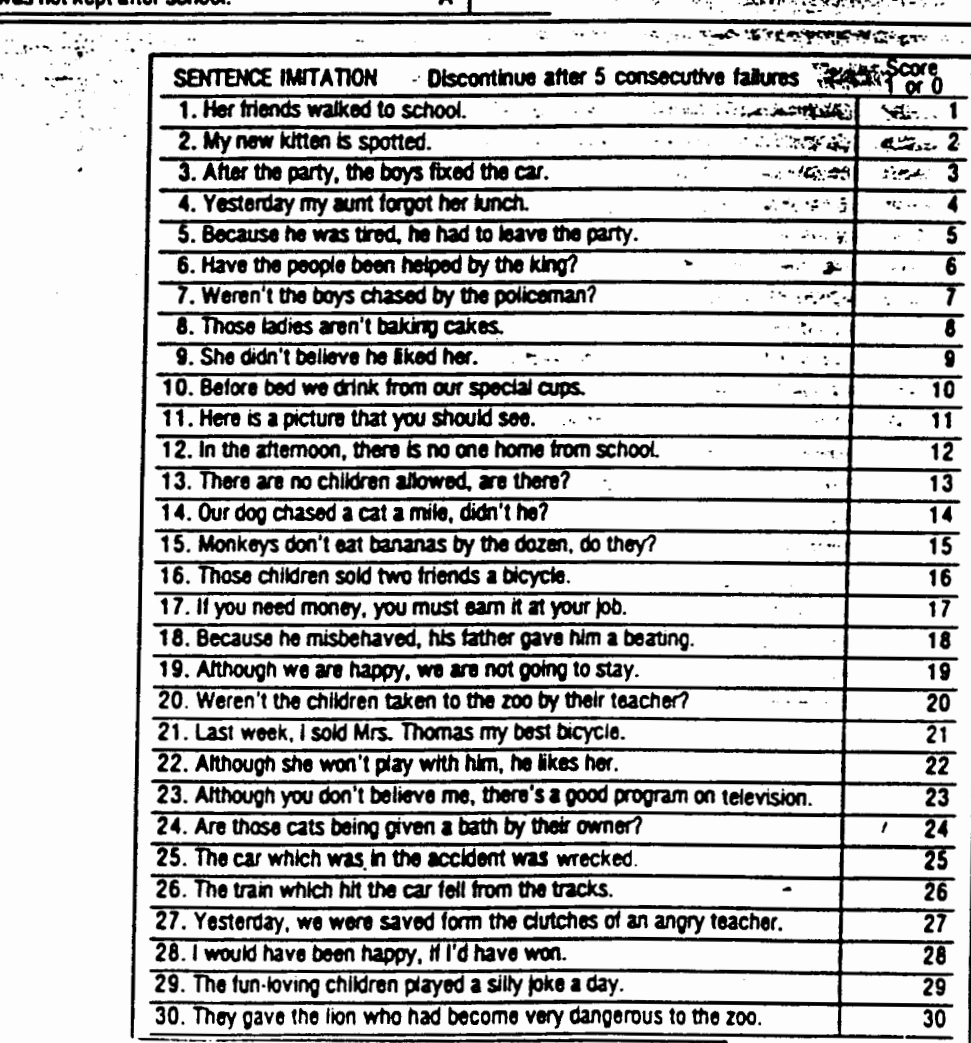



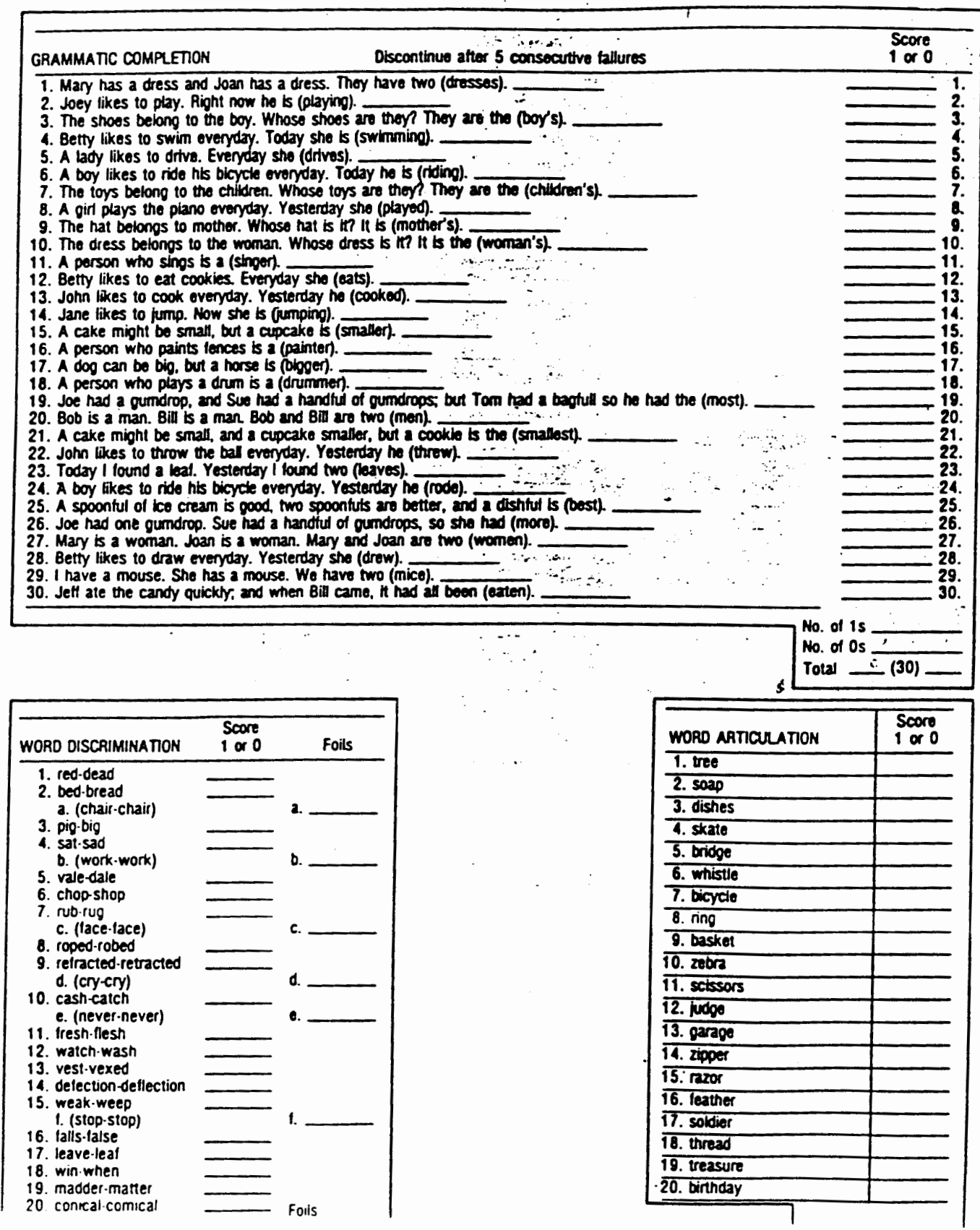

\begin{tabular}{|c|c|}
\hline WORD ARTICULATION & $\begin{array}{l}\text { Score } \\
1 \text { or } 0\end{array}$ \\
\hline \multicolumn{2}{|l|}{ 1. tree } \\
\hline \multicolumn{2}{|l|}{$2.502 p$} \\
\hline \multicolumn{2}{|l|}{ 3. dishes } \\
\hline \multicolumn{2}{|l|}{ 4. skate } \\
\hline \multicolumn{2}{|l|}{ 5. bridge } \\
\hline \multicolumn{2}{|l|}{ 6. whistle } \\
\hline \multicolumn{2}{|l|}{ 7. bicycle } \\
\hline \multicolumn{2}{|l|}{ 8. ing } \\
\hline \multicolumn{2}{|l|}{ 9. Dasket } \\
\hline \multicolumn{2}{|l|}{ 10. zetra } \\
\hline \multicolumn{2}{|l|}{ 11. sctsors } \\
\hline \multicolumn{2}{|l|}{ 12. 1udgo } \\
\hline \multicolumn{2}{|l|}{ 13. parage } \\
\hline \multicolumn{2}{|l|}{ 14. cipper } \\
\hline \multicolumn{2}{|l|}{ 15: razor } \\
\hline \multicolumn{2}{|l|}{ 16. leather } \\
\hline \multicolumn{2}{|l|}{ 17. soldier } \\
\hline \multicolumn{2}{|l|}{ 18. thread } \\
\hline \multicolumn{2}{|l|}{ 19. treasure } \\
\hline 20. birthday & \\
\hline
\end{tabular}


APPENDIX G

SUBJECT DATA 
DATA FOR THE DEPENDENT VARIABLES FROM THE SELD GROUP

\begin{tabular}{|c|c|c|c|c|c|c|c|c|}
\hline subject & & & NSST* & TACL * & & & & $L D$ \\
\hline & D & $\mathbf{s}$ & & & $' 88$ & 189 & $L$ & $S$ \\
\hline 6 & 3 & 1 & 0 & 9 & 3.74 & 6.36 & 20 & 37 \\
\hline 7 & 1 & 0 & 0 & 17 & 2.82 & 6.44 & 25 & 33 \\
\hline 29 & 4 & 0 & 0 & 29 & .43 & 4.24 & 27 & 28 \\
\hline 53 & 6 & 0 & 0 & 31 & 6.12 & 8.18 & 22 & 43 \\
\hline 54 & 0 & 0 & 1 & 36 & 3.4 & 5.63 & 14 & 34 \\
\hline 57 & 2 & 3 & 4 & 33 & 4.97 & 8.18 & 32 & 36 \\
\hline 85 & 3 & 1 & 0 & 15 & 2.72 & 5.70 & 15 & 33 \\
\hline 87 & 6 & 1 & 6 & 27 & 4.48 & 7.90 & 41 & 45 \\
\hline 92 & 3 & 0 & 0 & 77 & 5.48 & 4.10 & 34 & 39 \\
\hline 102 & 1 & 0 & 0 & 20 & 4.05 & 8.08 & 23 & 36 \\
\hline 105 & 0 & 0 & 0 & 39 & 4.80 & 6.68 & 38 & 49 \\
\hline 114 & 4 & 1 & 0 & 36 & 2.05 & 6.67 & 23 & 37 \\
\hline 115 & 4 & 0 & 1 & 14 & 2.81 & 5.77 & 12 & 26 \\
\hline 119 & $\underline{5}$ & $\underline{4}$ & 18 & 34 & 4.66 & 5.26 & 18 & $\underline{44}$ \\
\hline $\mathrm{X}:$ & & 786 & 2 & 30 & .75 & .37 & & \\
\hline
\end{tabular}

*PLS, NSST and TACL are raw scores.

DSS and TOLD are standard scores. 
DATA FOR THE DEPENDENT VARIABLES FROM THE NORMAL GROUP

\begin{tabular}{|c|c|c|c|c|c|c|c|c|}
\hline subject & & & NSST-E & TACL & & & & \\
\hline & $\mathrm{D}$ & $S$ & & & ' 88 & .89 & L & $S$ \\
\hline 14 & 5 & 1 & 2 & 29 & 2.72 & 4.07 & 33 & 36 \\
\hline 51 & 5 & 1 & 2 & 29 & 2.72 & 4.07 & 33 & 36 \\
\hline 55 & 5 & 4 & 14 & 41 & 4.72 & 5.66 & 33 & 36 \\
\hline 58 & 5 & 4 & 8 & 35 & 8.16 & 7.92 & 38 & 44 \\
\hline 63 & 5 & 3 & 3 & 38 & 5.22 & 6.33 & 27 & 50 \\
\hline 72 & 4 & 3 & 15 & 23 & 4.62 & 6.70 & 24 & 38 \\
\hline 95 & 6 & 4 & 0 & 22 & 5.72 & 5.50 & 20 & 42 \\
\hline 128 & 6 & 4 & 20 & 43 & 7.40 & 5.58 & 32 & 53 \\
\hline 130 & 6 & 2 & 1 & 43 & 4.80 & 8.62 & 38 & 47 \\
\hline 131 & 5 & 4 & 12 & 37 & 4.48 & 8.08 & 39 & 42 \\
\hline 132 & 6 & 3 & 0 & 37 & 5.51 & 8.04 & 34 & 36 \\
\hline 133 & 6 & 4 & 20 & 36 & 6.46 & 8.34 & 21 & 38 \\
\hline 144 & 2 & 4 & 13 & 36 & 5.56 & 6.14 & 37 & 51 \\
\hline 150 & $\underline{6}$ & $\underline{3}$ & 21 & $\underline{63}$ & 7.82 & 6.70 & 38 & 41 \\
\hline$X:$ & 5 & 3 & 9 & 37 & 5.42 & 6.55 & 32 & 42 \\
\hline
\end{tabular}

